\title{
WORKING
}

paper

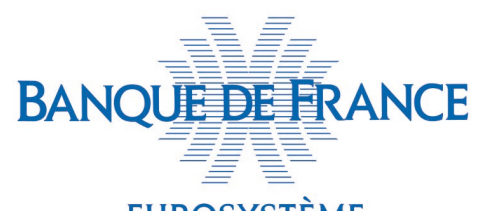

EUROSYSTÈME

\section{How Do Short-term Financial Constraints Affect SMEs' Long-Term Investment: Evidence from the Working Capital Channel}

\author{
Théo Nicolas ${ }^{1}$
}

\author{
October 2019, WP \# 731
}

\begin{abstract}
This paper investigates the real effects of short-term financial constraints in the light of the working capital channel: cash credit constraints may force SMEs to forgo investment opportunities in order to finance their working capital needs. Building on unique indicators of cash and investment credit constraints derived from survey data, I find that: (1) shortterm credit constraints are as important as long-term ones in SMEs' investment decisions; (2) the detrimental effect of cash credit constraints on corporate investment is even stronger for firms with higher working capital needs; (3) the negative relationship between working capital and fixed investment is associated with short-term financial frictions; and (4) only liquid SMEs are able to offset short-term financial frictions by adjusting their accounts receivable and inventories.
\end{abstract}

Keywords: Investment, Bank credit, Financial constraints, Working capital, Survey data.

JEL classification: D82; E32; E51; G01; G21.

\footnotetext{
${ }^{1}$ Data and Analytical Services Directorate, Banque de France, theo.nicolas@,banque-france.fr. The author is grateful to Jérome Coffinet, Jézabel Couppey-Soubeyran, Olena Havrylchyk, Amine Tarazi, Jean-Charles Rochet, Laurent Clerc, Jean-Bernard Chatelain, Serafeim Tsoukas and seminar participants at the Banque de France and the 7th EFI Workshop for helpful comments.
}

Working Papers reflect the opinions of the authors and do not necessarily express the views of the Banque de France. This document is available on publications.banque-france.fr/en 


\section{NON-TECHNICAL SUMMARY}

Despite the link between short-term finance and the working capital needs, the literature examining the firm level implications of financing frictions has traditionally focused on long-term liabilities. However, given the very specific financial features of SMEs, shortterm credit constraints are likely to have significant effects on capital accumulation. Under imperfect capital market assumptions, firms that exhibit the highest agency problems (i.e. SMEs) primarily rely on internal financing capacity and prefer debt to equity if external financing is required. According to this view, firms that are identified as financially constrained also show higher investment-cash flow. In this context, cash-flow uses become of primary interest and working capital needs may compete with fixed investment for the available pool of finance.

In modern corporate finance, working capital accounts for the net position of firms' liquid assets, both real and financial. It is defined as the sum of accounts receivable and inventories minus accounts payable and other non-financial debts due in less than one year. In other words, working capital refers to the funds available and used for daily operations of an enterprise. In this regard, one central motivation of this paper is the specific importance of working capital for SMEs in particular for sectors such as retail, construction or manufacturing where inventory management is a major issue.

To assess the real effects of financial constraints, my empirical analysis hinges on two different approaches which both take advantage of the quarterly French survey on the access to finance for SMEs. Following the ECB's "Survey on the Access to Finance of Enterprises" (SAFE), the French survey was started in Q1 2012 and aims to provide information on the SMEs' experience in attempting to access finance. Most importantly for my research, the questionnaire is the first to focus on loan maturity distinguishing shortterm from long-term loan applications. By summarizing quarterly responses, I am able to construct yearly indicators of investment and cash credit constraints that can be matched with Firms' balance sheet information.

Making use of qualitative survey data on the access to finance of almost 8,000 independent SMEs, I implement both matching estimator techniques and dynamic panel specifications to assess the effect of short-term financial constraints on corporate investment. All in all, I find that short-term credit constraints are at least as important as long-term ones for SMEs' investment decisions. In the presence of cash credit constraints, working capital needs compete with fixed investment to the extent that liquid assets such as accounts receivable and inventories cannot be monetized so easily. Hence, cash credit constraints may force SMEs to forgo investment opportunities in order to finance their working capital needs.

Importantly, the detrimental effect of short-term credit constraints on corporate investment is stronger for firms with higher working capital needs, while the negative relationship between working capital and fixed investment is associated with short-term financial frictions. In the end, only highly liquid firms are able to partially offset the impact of short-term financial constraints on fixed investment by monetizing their current assets. 


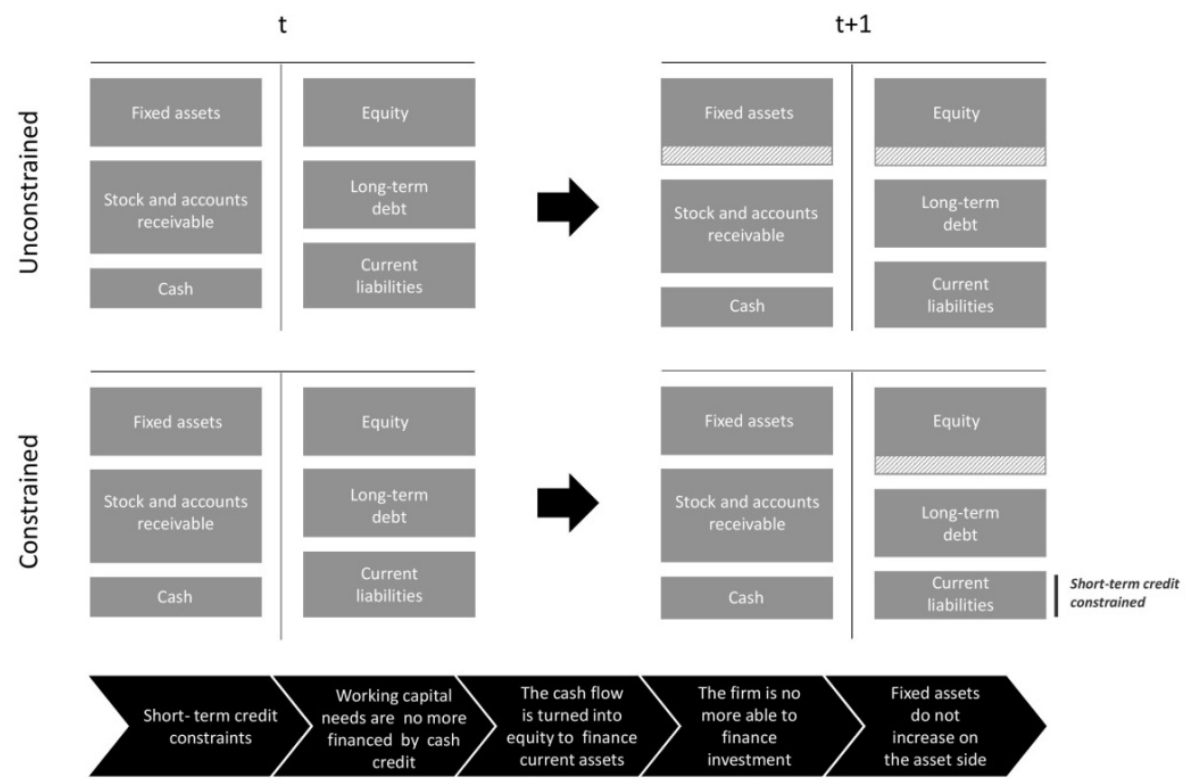

Interpretation: while in time $t$ no firms are credit constrained, in time $t+1$ constrained firms become short-term credit constrained and their current liabilities decrease. Hence, their working capital needs are no more financed by cash credit and short-term credit constrained firms are forced to turn their cash-flow into equity to finance their currents assets, thus maintaining the same balance sheet size. In contrast, firms which are not short-term credit constrained are able to turn their cash-flow into fixed assets to increase their balance sheet.

\title{
Comment les contraintes financières à court terme affectent-elles l'investissement à long terme des PME ? Le cas du canal du besoin en fonds de roulement
}

\begin{abstract}
RÉSUMÉ
Ce papier examine les effets réels des contraintes financières à court terme à la lumière du canal du fonds de roulement : les contraintes de crédit de trésorerie peuvent obliger les PME à renoncer à des opportunités d'investissement afin de financer leurs besoins en fonds de roulement. En m'appuyant sur de nouveaux indicateurs de contraintes de crédit de trésorerie et d'investissement tirés de données d'enquête, je constate que : (1) les contraintes de crédit à court terme sont aussi importantes que les contraintes de crédit à long terme dans les décisions d'investissement des PME ; (2) l'effet négatif des contraintes de crédit de trésorerie sur l'investissement des entreprises est encore plus fort pour les entreprises ayant des besoins en fonds de roulement plus élevés ; (3) la relation négative entre le besoin en fonds de roulement et les investissements fixes est associée aux frictions financières à court terme ; (4) seules les PME liquides peuvent compenser leurs difficultés financières à court terme en ajustant leurs stocks et leurs créances clients.
\end{abstract}

Mots-clés : Investissement, Crédit bancaire, Contraintes financières, Besoin en fonds de roulement, Enquête. 


\section{Introduction}

Despite the link between short-term finance and working capital needs, the literature examining the firm level implications of financing frictions has traditionally focused on longterm liabilities (Bernanke \& Gertler, 1989, Kiyotaki \& Moore, 1997, Holmstrom \& Tirole. 1997). However, given the very specific financial features of SMEs, short-term credit constraints are likely to have significant effects on capital accumulation. Under imperfect capital market assumptions, firms that exhibit the highest agency problems (i.e. SMEs) primarily rely on internal financing capacity and prefer debt to equity if external financing is required (Myers \& Majluf, 1984). According to this view, firms that are identified as financially constrained also show higher investment-cash flow sensitivity (Fazzari et al., 1988, Gilchrist \& Himmelberg, 1995; Mulier et al., 2016). In this context, cash-flow uses become of primary interest and working capital needs may compete with fixed investment for the available pool of finance (Fazzari \& Petersen, 1993).

The crucial role of working capital has been recognized since the emergence of classical economics 2 In modern corporate finance, working capital accounts for the net position of firms' liquid assets, both real and financial. It is defined as the sum of accounts receivable and inventories minus accounts payable and other non-financial debts due in less than one year. In other words, working capital refers to the funds available and used for daily operations of an enterprise. In this regard, one central motivation of this paper is the specific importance of working capital for SMEs' (see Figure 1], in particular for sectors such as retail, construction or manufacturing where inventory management is a major issue $3^{3}$. For instance, in 2016, inventories and accounts receivable combined represented on average almost $40 \%$ of firms' total assets and this figure reached $50 \%$ in the construction sector (see Figure $3 \sqrt{4}$

2 Following the work of the physiocrats, Smith (1776) made the first explicit distinction between fixed and circulating capital.

3 In line with the European Commission, my definition of SMEs is based on number of employees (less than 250), turnover (less than EUR 50 million) and total assets (less than EUR 43 million).

4 Computations are made using the Fiben database described below. 
To assess the real effects of financial constraints, my empirical analysis hinges on two different approaches which both take advantage of the quarterly French survey on the Access to Finance for SMEs. Following the ECB's "Survey on the Access to Finance of Enterprises" (SAFE), the French survey was started in Q1 2012 and aims at providing information on the SMEs' experience in attempting to access finance. Most importantly for my research, the questionnaire is the first to focus on loan maturity distinguishing short-term from longterm loan applications. By summarizing quarterly responses, I'am able to construct yearly indicators of investment and cash credit constraints that can be matched with firms' balance sheet information $5^{5}$ I end up with 2,225 (resp. 4,220) independent SMEs that exhibit a yearly positive demand for cash (resp. investment) credit, representing 3,655 (resp. 9,801) observations.

First, I use a quasi-randomized approach using matching estimator techniques that minimize concerns about selection. In doing so, I'am able to isolate treated observations (i.e. firms reporting financial constraints in the French survey on the Access to Finance for SMEs) and then, from the population of non-treated observations, look for control observations that best match the treated ones regarding a set of determinants of investment spending. In the end, I conjecture that the treated group's investment choices would have been the same as the control group if it had not been treated. Generally speaking, instead of comparing the average difference in investment across all constrained and unconstrained firms, I compare the differences in the average investment rates of firms that are similar.

The matching approach reveals significant cross-sectional variations in corporate investment between credit constrained firms and their unconstrained counterparts. While both kind of credit constraints are associated with a lower investment, I find that short-term credit constraints have the same impact as long-term ones on SMEs' fixed investment (i.e. tangible and intangible). Thus, the average difference in annual increase in all fixed assets between credit

$5 \quad$ Note that I rule out from the analysis firms that were simultaneously credit constrained regarding both cash and investment credit in order to separately identify the causal effect of each credit constraint. 
constrained firms and their controls reaches 90 basis points of total assets which amounts to a decrease of around $24 \%$. Those results are robust to alternative matching methods and quantile regressions.

Thereafter, recognizing the limitations of the matching procedure, I complement the analysis with a two-step dynamic panel methodology in order to control for both unobserved time-invariant heterogeneity and lagged investment structure. Taking into account the changing composition in loan demand by means of a Heckman probit model, the first step estimates the firms' probability of being financially constrained as a function of their financial situation. I end up with two different scores allowing me to create two indexes: an Index of Cash Credit Constraints (ICCC henceforth) and an Index of Investment Credit Constraints (IICC henceforth). From there, the second step consists in incorporating these indicators into a standard dynamic model of investment.

The estimations are quantitatively lower than the above-mentioned non-parametric analysis. Yet, the measure of cash credit constraints turns out to be negative and significant for all specifications, indicating that short-term credit constraints matter for corporate investment. Besides, the economic importance of cash credit constraints is close to the measure of investment credit constraints with an average decrease in investment spending of $12 \%$ : a short-term (resp.long-term) financial constraint decreases the annual increase in all fixed assets by 40 (resp. 50) basis points of total assets. Importantly, working capital needs turn out to negatively affect investment decisions, but only for short-term credit constrained firms. The higher the working capital need, the more cash credit constraints are detrimental to firms' investment. In addition, interacting cash flow with my indexes of credit constraints, I find that credit constrained firms do not exhibit higher investment-cash flow sensitivities. Finally, investigating the firms' ability to sidestep those credit constraints I show that short-term credit constrained firms that exhibit higher amounts of accounts receivable or inventories experience a lower decrease in their investment than the others. Those results are robust to the inclusion of other instruments such as leverage and deeper lags of the existing variables. 
This paper contributes to a classic strand of research in corporate finance investigating how financial constraints and fluctuations in credit supply might affect investment (Fazzari) et al., 1988, Hoshi et al., 1991; Kaplan \& Zingales, 1997; Almeida \& Campello, 2007; Aghion et al. 2012). In particular, my work is close to the increasing literature that attempts to assess the real effects of firms' financial constraints using methods inspired by observational studies (Lemmon \& Roberts, 2010; Duchin et al., 2010; Almeida et al., 2012; Kahle \& Stulz, 2013). The latter use matching estimators or difference-in-difference methodologies to compare the evolution of capital expenditure of treated (i.e. constrained) firms relative to their controls (i.e. unconstrained). While their identification strategy relies on firms' exposure to credit supply shocks, I follow Campello et al. (2010) and take advantage of the recent advances in data collection to use loan application outcomes as direct information as to a firms' ability to obtain external funds.

My results also relate to the vast literature on the role of credit cycles in driving fluctuations in economic activity through the so-called financial accelerator (Bernanke \& Gertler, 1989; Kiyotaki \& Moore, 1997). Under financial market imperfections, economic shocks are both amplified and propagated over time as they affect firms' balance sheet positions. For example, adverse economic shocks reduce firms' net worth, limiting their ability to borrow, and further reducing their net worth over time. Drawing on the working capital channel literature (Fazzari \& Petersen, 1993; Almeida et al., 2017)6 I stand apart from the above mentioned articles by emphasizing the role of short-term finance on real economic output.

Finally, this paper contributes to the literature focusing on indicators of financial constraints. Since the seminal work of Fazzari et al. (1988), financially constrained firms (i.e. firms with low dividend payout ratios) are meant to exhibit higher investment-cash flow sensitivities (henceforth ICFS). Nonetheless, numerous studies have subsequently cast some doubt on the ICFS hypothesis (Kaplan \& Zingales, 1997; Kadapakkam et al., 1998; Cleary, 2006). Above all, the usual strategy hinges on an indicator which is unidimensional, time-invariant

$\overline{6}$ I discuss this literature in greater detail below. 
and restricted to quoted firms. Hence, I implement a multidimensional analysis (Cleary, 1999; Lamont et al., 2001; Whited \& Wu, 2006) to construct a time-varying indicator of financial constraints and find that the negative relationship between fixed and working capital needs is associated with short-term credit frictions. To my knowledge, this paper is the first to create such an indicator of both cash and investment credit constraints using qualitative survey data of small private firms.

The remainder of the paper is structured as follows. Section 2 presents the related literature associated with the working capital channel and the testable hypotheses. Section 3 presents the data and the summary statistics. Section 4 and 5 examine the real effects of financial constraints on corporate investment using a quasi-randomized approach and a dynamic panel analysis, respectively. Section 6 discusses the robustness of the results and Section 7 concludes.

\section{The working capital channel}

\subsection{Related literature}

The firm level implications of working capital under financial constraints have received little attention in the literature which traditionally focuses on long-term finance (Bernanke \& Gertler, 1989; Kiyotaki \& Moore, 1997; Holmstrom \& Tirole, 1997). However, a more recent stream of papers dealing with macroeconomic implications of financial frictions over the business cycle suggest that working capital can have significant effects on real output through financial accelerator and supply conditions (Mendoza, 2010; Jermann \& Quadrini, 2012 7 The main argument lies in inventory management whenever firms need to pay for inputs in advance of production. Given that firms' production capacity relies on their ability to finance their working capital, a short-term credit constraint may amplify the effect of economic shocks on their sales. Looking at the effect of oil shocks on firm profitability, Almeida

7 In addition, the potential importance of these working capital effects has also been stresses in studies of monetary policy shocks, as interest rates changes affect supply conditions (marginal costs) through nominal rigidities in the presence of sticky wages (Christiano et al., 2005). 
et al. (2017) empirically found that working capital finance can be an important channel for understanding how the credit multiplier affects economic activity. More precisely, the effects of shocks to input prices are amplified by endogenous changes in net worth: as firms' profit and net worth are reduced, the latter find it difficult to finance their inventories, which ends up with a further decrease of their sales, profits, net worth, production capacity and so on.

While this working capital channel examines the propagation of shocks over time in the light of firms' production decisions, some authors have attempted to assess the effect of working capital on investment demand in presence of financial constraints. Developing the atypical role of working capital as both an input and a readily reversible store of liquidity, Fazzari \& Petersen (1993) show that working capital can act as an alternate source of financing to external capital, especially for the purpose of fixed-investment smoothing in order to maintain a stable fixed-investment path ${ }^{8}$. Thus, even constrained firms can offset the impact of cash-flow shocks on fixed investment by adjusting working capital. Hence, the authors find a negative coefficient on working capital in a reduced-form investment model. What is more, the firm ability to smooth investment in fixed assets is likely to be higher for highly liquid firms.

Building on this second strand of literature, this paper analyzes the demand-side effect of short-term financial constraints that can reduce the aggregate level of investment. Under the working capital channel, working capital needs may compete with fixed investment whenever financial constraints are binding. Following the pecking order theory (Myers \& Majluf, 1984), I assume that short-term financial constraints prevent SMEs to seize investment opportunities by forcing them to allocate additional cash-flow to finance their working capital (see Figure ?? for the explanatory diagram). Yet, contrary to the investment smoothing hypothesis based on working capital, I presume that firms cannot monetize their liquid assets so easily, thus both adjusting their working capital and fixed investment. In addition, since changes

$8 \quad$ As marginal adjustment costs of acquiring and installing capital rise as the rate of investment increases, firms are willing to maintain a stable fixed investment path (Lucas Jr, 1967). 
in working capital are likely to be positively related to business cycle (Gertler \& Gilchrist, 1994; Fazzari \& Petersen, 1993), the fact that working capital is significantly and negatively related to fixed investment for cash credit constrained firms should be an indicator of capital market imperfections in the short run.

\subsection{Research Hypotheses}

The literature focusing on how working capital and short term credit constraints affect corporate investment yields 4 key testable hypotheses:

(H1) Short-term credit constraints negatively affect corporate investment.

(H2) The detrimental effect of short-term credit constraints on corporate investment is stronger for firms with higher working capital needs.

(H3) The negative relationship between fixed and working capital needs is only associated with short-term credit frictions.

(H4) Highly liquid firms (i.e. with numerous current assets) are more able to offset the impact of short-term financial constraints on fixed investment.

To convincingly address these issues, I use both a parametric and a non-parametric approaches to assess the effect of credit constraints on corporate investment according to loan maturity. In the following section, I first describe the various sources of data I merged and the variables involved.

\section{Data and summary statistics}

Combining two different supervisory databases available at the Banque de France, this study relies on a unique dataset of independent SMEs covering the period 2012-2016. The loan application outcomes stem from the survey on the Access to Finance of SMEs gathered by the Banque de France, while the firm level data comes from the Banque de France database on non-financial firms. 


\subsection{Measures of financial constraints}

The core firm-level data comes from the quarterly French Survey on the access to Finance of SMEs. Following the ECB's "Survey on the Access to Finance of Enterprises" (SAFE), the French survey started in Q1 2012 after the financial crisis initially hit the Euro area and aims at providing information on the financing needs of SMEs and their experience in attempting to access finance. Unlike the SAFE survey which contains information on a respondent firm's characteristics (size, sector, firm autonomy, turnover, firm age and ownership), the survey focuses on the assessment of recent short-term developments regarding its financing including information on its access to finance. Most importantly, the questionnaire is the first to focus on loan maturity distinguishing short-term loan applications from long-term ones. The survey contains only non-financial firms and excludes firms in agriculture, public administration and financial services 9

In the first question of the questionnaire firms are asked whether they belong to a holding company or not. If so, non independent SMEs are ruled out from the sample, thereby avoiding the difficulty relating to financial flows between holdings and SME subsidiaries of a corporate group (Kremp \& Sevestre, 2000). This selection process retains 92,488 quarterly observations representing 7,778 independent SMEs. Thereafter, firms are asked whether they have had a positive demand for cash (resp. investment) credit over the previous quarter. Out of these observations, only $6.46 \%$ (resp. $19.85 \%$ ) exhibit a quarterly positive demand for cash (resp. investment) credit, representing 5,981 (resp. 18,364) observations and 2,509 (resp. 4,582) independent SMEs. Besides, the survey enables to follow firms over time. Thus, over the sample period of 20 quarters, SMEs exhibit a positive demand for cash (resp. investment) credit during, on average, 2.5 (resp 4) quarters.

Summarizing quarterly responses to obtain annual information, I consider that a firm exhibits a yearly positive demand for cash or investment credit whether it has applied for

$9 \quad$ One should keep in mind that the manufacturing sector is over-represented in the sample (50\%) so that the survey cannot be interpreted as a representative estimate of the opinion French firms have on their credit conditions. 
those loans during at least one of the four quarters of the year. In the end, I rule out from the analysis firms that were simultaneously both cash and investment credit constrained in order to clearly distinguish these two different accesses to finance. This process leaves me with 2,442 (resp. 4,500) independent SMEs that exhibit a yearly positive demand for cash (resp. investment) credit, representing 4,014 (resp. 10,335) observations.

According to the standard definition of financial constraints, I'm able to define a firm as "yearly constrained" when it does not obtain the loans it has applied for during the year. More precisely, a firm is considered as cash (resp. investment) credit constrained during the year ${ }_{t}$ in three different cases: a) the quarterly firm's application for a liquidity (resp. investment) loan was denied at least once per year(loan application denied); b) the firm received less than $75 \%$ of the quarterly loan amount it requested at least once per year (rationed); c) the firm refused the quarterly loan offer because the rate was too high at least once per year (refused due to high cost). Alternatively, the firm is considered as not cash or investment credit constrained whether its quarterly loan applications were totally approved or at least if the firm obtain more than $75 \%$ of the loans amounts it requested over the year. Despite its yearly basis, the classification is in line with how studies using the semi-annual SAFE survey define the loan supply (Ferrando \& Mulier, 2015). More generally, this approach is common to the literature that uses survey data to study credit access (Popov \& Udell, 2012; Jiménez et al., 2012).

Overall, short-term credit constraints turn out to be more salient in France. 1 reports the qualitative yearly indicators of credit constraints for the two different loan maturity. Out of the 3,655 $(9,801)$ cash (resp. investment) loan applications (i.e. firms that exhibit a yearly positive demand for cash or investment loan, respectively), $13.30 \%$ (resp. $4.84 \%$ ) are on average "yearly constrained" over the sample period 2012-2016. In this regard, one should note that those constraints have constantly decreased since the beginning of the survey. Note that Table 3 explains in detail the number of initial firms and observations that are available and then how many are lost during each step. 


\subsection{Comparisons with standard proxies for financial constraints}

One should wonder what is the relationship between these direct measures of credit constraints and a priori criteria of financial constraints. To investigate this issue, I estimate of a logit model in which traditionnal indicators of financial constraints are used to explain my indicators of short-term or long-term credit constraints: the Whited-Wu (WW) index, the Kaplan-Zingales (KZ) index ${ }^{10}$ the Hadlock-Pierce (HP) index (note that all four indices are supposed to be increasing with financial constraints). Finally, I also include the Banque de France speculative grade ${ }^{11}$ Coefficients of Table 4 indicate that the correlation is low (with WW and KZ for cash credit constraints and HP for investment credit constraints) or even not significant (with HP for cash cash credit constraints and WW and $\mathrm{KZ}$ for investment credit constraints). These results are not surprising given that the existing indices were built using data on quoted US firms while my direct indicators are based on unquoted European SMEs. Besides, this low correlation is consistent with a recent research which suggests that the existing indices do not properly capture financial constraints (Farre-Mensa \& Ljungqvist, 2016). However, regarding the Banque de France rating, the speculative grade turns out to be strongly and positively correlated with my qualitative indicators of financial constraints.

\subsection{What are financially constrained firms like?}

To account for the observable firm heterogeneity driving financial constraints, I match the yearly credit constraints indicators with firm's balance sheet information coming from the FIBEN (Fichier Bancaire des Entreprises) database. The later gathers accounting and

10 Given the lack of market data available for unquoted SMEs, traditional variables such as Tobin's Q or Fundamental Q cannot be computed. Following Honda \& Suzuki (2000), D'Espallier \& Guariglia (2015) developed an accounting proxy for marginal Q to control for investment opportunities. Their marginal Q is defined as the ratio of profit per unit of capital over the cost of capital.

11 This credit ratings belongs to the in-house credit assessment systems (ICAS) validated by the Eurosystem, which means that the Eurosystem can rely on it when assessing the credit quality of eligible credit claims within its collateral framework. The information gathered and analyzed by the Banque de France is used to conduct a comprehensive assessment of a company's credit risk. The data are based on hard information such as balance sheet data, payment incidents data etc., as well as soft information gathered from interviews with company managers. Low, speculative-grade, BdF ratings rank from 9 to $5+$. 
financial data from the balance sheet on all companies with a turnover of at least $750,000 €$ since 1990. Based on fiscal documents, firm's information is yearly collected by the Banque de France at the legal entity level (non-consolidated), through a unique national identifier called SIREN. In 2016, this dataset contains individual company accounts for 250, 000 firms. These firms represent a third of all companies taxed under the «bénéfice industriel et commercial» or «bénéfice réel normal» regimes (Kremp \& Sevestre, 2013). The database thus covers a large share of the French economy. Above all, a great advantage of FIBEN is that it enables to focus on non listed SMEs that are often neglected by American studies based on the Compustat database.

To perform the analysis, I first rely on a traditional set of measures that potentially affect the bank loan supply, comprising the cash flow ratio (i.e. the ratio of cash flow over total assets of the firm), the cash ratio (i.e. the ratio of cash holdings over total assets of the firm), the capital ratio (i.e. the ratio of own funds over total assets of the firm) and variables that typically proxy the presence of asymmetric information such as firm size and age. To minimize the impact of gross outliers, I winsorize variables at the top and bottom first percentile. All the definitions of the variables I use in this paper are summarized in Table 2 .

Considering that a large number of firms in my sample are not asking for a short-term or a long-term loan, one may be interested in knowing what are the main differences between firms that apply for a loan and those that do not. According to loan maturity, Table 5 presents those descriptive statistics and tests the equality of the median of both groups. In particular, some of the differences between these two groups are compatible with the idea that credit demand depends on financial soundness: applicant firms turn out to be less solvent and less liquid regardless of the type of loan. Besides, Short-term credit applicants are also less profitable than non applicant ones. These different sources of funding are likely to be negatively correlated with the need for bank credit 12 . However, some other differences point to the

12 In this regard, note that in 2015 the Banque de France included questions about the reasons why firms do not ask for bank credit in order to gauge the level of "discouraged borrowers": only $2 \%$ of French SMEs are associated with such a phenomenon 
opposite conclusions. For instance, long-term credit applicants are more profitable than non applicant ones. One interpretation could be that a higher cash flow also captures better investment opportunities which in turn encourages firms to take out a loan. In addition, larger firms are more willing to ask for a cash credit while it is the opposite for investment credit.

Regarding financial constraint status, Table 6 finally reports the same descriptive statistics. This time the figures are clear and unambiguous. Overall, firms with financial constraints tend to be less profitable, less liquid, more leveraged, younger and smaller than firms without financing constraints, which is in line with the empirical literature(Ferrando \& Mulier, 2015).

\subsection{How do financial constraints relate to corporate investment?}

An investment is commonly perceived as the purchase of goods that are not consumed today but are used in the future to create wealth. Following the empirical literature on corporate investment (Fazzari et al., 1988; Kaplan \& Zingales, 1997; Kahle \& Stulz, 2013; Asker et al., 2014), I measure gross investment as the annual increase in gross fixed assets (i.e. gross property, plant and equipment) scaled by beginning-of-year total assets ${ }^{13}$. In addition, I also construct another measure of investment using both tangible and intangible assets such as patents, copyrights, trademarks and franchises.

To illustrate how financial constraints described previously are related to corporate investment, Table 7 performs median tests to compare corporate investment according to short-term and long-term credit constraints. Thereby, short-term credit constrained firms exhibit a corporate investment (both in tangible and intangible assets) which is one percentage point lower than their unconstrained counterparts. As for investment credit, this assessment is similar and approximates -80 basis points. Financial constrained firms are therefore associated with lower investment spending. Yet, to truly investigate this issue, one have to verify whether this difference still holds when dealing with constrained and unconstrained firms with similar characteristics.

13 To the extent that depreciation is likely to be somewhat arbitrary, I assume that gross investment better captures a firm's investment decision. 


\section{A non parametric matching approach}

\subsection{Searching for counterfactuals}

Given the very specific nature of SMEs and the "working capital channel" introduced above, short-term credit constraints are expected to have substantial real effects. To gauge those effects, I take advantage of a quasi randomized experiment in which firm financial status can be seen as a "treatment". I want to test whether firms' financial constraints affect long term corporate decisions according to loan maturity. Importantly, as pointed out previously, I ruled out from the analysis firms that were simultaneously credit constrained regarding both cash and investment credit in order to identify separately the causal effect of each credit constraints. To addresses this issue my empirical strategy first hinges on matching estimator techniques that minimize concerns about selection.

The idea behind this family of estimators consists of isolating treated observations (i.e. firms facing financial constraints) and then, from the population of non-treated observations, look for control observations that best "match" the treated ones regarding a set of covariates. In this estimation framework, the number of counterfactuals are restricted to the matched controls. To put it differently, I conjecture that the treated group would have behaved as the control group actually did if the treated group had not been treated ${ }^{14}$

To this end, my identification needs two conditions to be met: overlapping and unconfoundeness. The former require enough counterfactual firms that correspond to the treated ones. The second condition that must be satisfied to validate my strategy is that assignation to treatment needs to be exogenous to observed post-treatment outcomes (i.e. the so-called conditional independence assumption). In particular, one might worry that the same variables that determine credit constraints affect also post-credit constraints investment. For example, let's consider a firm coming from a more credit constrained sector in which financing needs

$14 \quad$ Inferences about the treatment of interest (i.e. financial constraints) are based on comparisons of the expost outcomes of treatment and control groups. In the treatment evaluation literature this difference is referred to as the average treatment effect for the treated, or ATT (see Imbens (2004) for a review). 
are lower. It would not be astonishing that this firm might both do worse during the treatment (e.g. invest less) and find less available credit.

Following the matching approach of Abadie \& Imbens (2006), as implemented by Abadie et al. (2004), I make use of a matching estimator that minimizes a measure of distance (the Mahalanobis distance) between all the control variables for firms in the treated group and their matches. The estimator allows control firms to serve as matches more than once, which compared with matching without replacement lowers the estimation bias (but can increase the variance). In my estimations, I select one matched control for each treated firm. The Abadie-Imbens estimator yields exact matches on categorical variables, while the matches on continuous variables are not exact but close. The procedure takes into account this limitation and applies a bias-correction component to the estimates of interest. In addition, the estimator produces heteroskedastic-robust standard errors 15

To ensure that covariates that might both influence the selection into treatment and observed outcomes are correctly accounted for in the estimation, I select determinants of corporate investment that could make a reasonable case for simultaneity in the treatment-outcome relation. Hence I match firms on two categorical variables (sector and year) and five continuous variables: cash-flow, investment opportunities, cash holdings, solvency and size as in Asker et al. (2014) ${ }^{16}$, Regarding investment opportunities, I use sales growth which has been widely used to replace Tobin'q in presence of private firms that are not traded on a stock exchange (Bloom et al., 2007; Michaely \& Roberts, 2011). At the same time, this choice sidesteps the traditional measurement error problem coming from the use of $\mathrm{Q}$ in investment demand equations (Erickson \& Whited, 2000; Cummins et al., 2006). Generally speaking, instead of comparing the average difference in policy outcomes across all of the constrained and all of the unconstrained firms, I now compare the differences in investment increase of

15 In particular, I use the bias-corrected, heteroskedasticity-consistent estimator implemented in Abadie et al. (2004).

16 Following the empirical literature on corporate investment, cash-flow, firm capital and cash holdings are beginning-of-year values scaled by beginning-of-year total assets of the firm. 
firms that are similar (i.e. matched) 17 .

\subsection{Summary statistics}

Table 8 reports the median values of the variables used in my matching procedure across various data groups. I use the continuity-corrected Pearson statistic to test for differences in the medians of the variables of interest across the groups. According to loan maturity, Panel A compares the 392 (resp. 399) short-term (resp. long-term) credit constrained firms (i.e treated firms) in our sample with the remaining 1,997 (resp. 4,097) firms that are not assigned into the short-term (long-term) credit constrained group (i.e. non-treated firms). Credit constrained firms turn out to have lower median profitability, cash holdings and investment opportunities (i.e. sale growth). Credit constrained firms are also smaller (except for the investment credit sample) and have a lower median capital ratio. As discussed above, these sample differences are expected, given that I'm relying on observational data rather than running a true experiment. The goal of matching estimator techniques is to control for these distributional differences, which could affect both the selection into the treatment and the post-financial constraint outcomes.

Thereafter, Panel B compares median values for treated and matched control firms. The Abadie-Imbens estimator identifies a match for each credit constrained firm as long as it is possible 18 As explained previously, the estimator allows control firms to serve as matches more than once. Thus, I end up with 208 firms (resp. 266 firms) in the short-term (resp. long-term) credit constrained group and 184 firms (resp. 258 firms ) in the control group. Importantly, there are no statistical differences in the median values of the covariates I consider across credit constrained firms and control firms.

Table 8 also compares the entire distributions rather than just the medians of the various matching covariates across the treated, non-treated and controls. Panel A shows that treated

17 Yet, as I do not know all of the factors that determine treatment assignment (i.e. financial constraints), I cannot make sure that that there is no hidden bias that could undermine my inference.

18 Based on overlapping tests, I select the best match using a caliper (i.e the maximum permitted difference between matched subjects) of 0.45 standard deviations. 
firms differ significantly from non-treated firms. In particular, a Kolmogorov-Smirnov test of distributional differences rejects the null hypothesis that distributions are identical at the $1 \%$ threeshold for all of the matching covariates. Once again, these differences disappear when I compare the treated firms to the group of closely-matched control firms. In particular, Panel B of Table 8 shows that there are no statistical differences in the distributions of the various matching covariates across the treated and control firms. These statistics support the assertion that the matching estimator moves my experiment closer to a test in which treatment and control groups differ only with respect to their access to finance.

\subsection{Matching results}

Turning to the real effects of financial constraints, I investigate the working capital channel introduced earlier to verify whether cash credit matters more than investment credit in firms' investment decision. Using the Abadie \& Imbens (2006) procedure, I'm now able to compare mean differences in annual increase in gross fixed assets between financial constrained firms and their counterfactual (i.e. matched pairs). Examining the average treatment effect on the treated, Table 9 shows that financial constraints turn out to have substantial effects on corporate investment.

Looking at columns (1), which presents the Abadie-Imbens estimates for cash credit, firms that report themselves as being short-term credit constrained appear to invest less in tangible assets. Thus, the average difference in annual increase in tangible assets between short-term credit constrained firms and their controls reaches 1.2 percentage point of total assets. Incorporating all fixed assets, this figure falls to 90 basis points. Given that the average corporate investment (tangible and intangible) equals 3.8\% of total assets for the whole shortterm credit sample, this effect is economically substantial and amounts to a decrease of around $24 \%$.

Regarding investment credit, column (2) indicates that long-term credit constraints affect significantly the firm willingness to invest in both tangible and intangible assets. In particular the effect of long-term credit constraints on tangible assets is lower: the average difference in 
annual increase in tangible investment between long-term credit constrained firms and their controls equals 70 basis points of total assets. Interestingly, incorporating both tangible and intangible assets, investment and cash credit constraints have the same negative impact on corporate investment (i.e. - 90 basis points). This counterintuitive result supports the working capital channel. Short-term financial constraints affect long-term investment, thus corroborating H1. Firms with opportunities to invest in positive net present value projects may be blocked from doing so because financial constraints may force them to allocate additional cash-flow to finance working capital need.

In the rest of the paper, I build on these results to address two further issues. First, it is important to recognize the limitations of the matching procedure. The matching procedure can control only for selection on observables. Thus, unobservable differences among the groups can potentially compromise my identification strategy if those unobservable differences are also correlated with the observable characteristics. Second, past corporate investment decisions may have substantial effects on current ones. To address these concerns, a dynamic panel methodology is therefore implemented.

\section{Dynamic panel analysis}

So far, firm unobserved heterogeneity and dynamic investment choices have not been taken into account. In this section, I use a two-step methodology to assess the effects of the working capital channel on the dynamic of capital accumulation. The first step is to exploit the information derived from the Banque de France survey used previously, and to link it with firms' financial characteristics. This is the ICC (Indicator of Credit Constraints) indicator. From there, the second step consists in incorporating the indicator of cash or investment credit constraints into a dynamic model of investment.

\subsection{Credit constrained firms: The ICC indicator controlling for selection bias}

Following Ferrando et al. (2015), the Indicator of Credit Constraints (ICC) defines firms that can be considered as credit constrained using information derived from their financial sit- 
uation. The analysis is based on a dataset which matches independent firms that participated in the Banque de France survey on access to finance with their FIBEN financial statements from Q1 2012 to Q4 2016. The construction of the index is based on several steps. The first step is the estimation of the equation which will be used in order to rank the firms according to their probability of being cash or investment credit constrained. Then, a threshold is obtained using the exogenous averages of credit constrained firms by year, taken from the Survey.

I estimate the probability of firms to be financially constrained as a function of their financial situation. In particular, based on the descriptive analysis presented in the previous section, I consider solvency, liquidity, profitability, and I control for other possible determinants like year and sector specific effects as well as the size and the age of the firm. However, this strategy would fail to account for the changing composition of firms that demand bank credit, or in other words, for the fact that the sample of firms that apply for credit is not a random sub-sample of the population of firms (Popov \& Udell, 2012). To tackle this sample selection issue, I control for information on non-applicant firms in a standard 2-step Heckman procedure. The idea is that credit constraints are only observable when a firm needs bank credit. Let the dummy variable D equal 1 if the firm applies for credit, and 0 otherwise. The value of $\mathrm{D}$ is in turn determined by the latent variable:

$$
d_{i t}=\rho Z_{i t}+e_{i t}
$$

Where $Z_{i t}$ contains variables pertinent to firm $i$ in year $t$ that may affect the firm fixed costs and convenience associated with using bank credit. The variable $\mathrm{D}=1$ if $\mathrm{d}>0$ and $\mathrm{Q}=$ 0 otherwise. The error $e_{i t}$ is normally distributed with mean 0 and variance $\sigma^{2}$. The second stage regression can now be updated by adding the term $\sigma \frac{\phi(d)}{\Phi(d)}$ to the RHS, where $\frac{\phi(d)}{\Phi(d)}$ is the inverse of Mills ratio (Heckman, 1979) derived from the first step. Identification rest on the exclusion restriction which requires that $d$ has been estimated on a set of variables that is larger by at least one variable than the set of variables in the second stage. Thereby, in the 
second stage in which I determine the effect of firm variables on the firm likelihood to be credit constrained, I estimate the following Heckman probit model:

$$
\text { Constrained }_{i t}=\beta_{1} X_{i t}+\beta_{2} \sigma \frac{\phi(d)}{\Phi(d)}+v_{j}+v_{t}+e_{i t}
$$

Where Constrained Cit $_{\text {is }}$ a dummy variable equal to 1 if firm $i$ is constrained by bank $b$ in year $t$ (according to the criteria outline in section 3 ); $X_{i t}$ is a matrix of firm characteristics accounting for creditworthiness; $\sigma \frac{\phi(q)}{\Phi(q)}$ is the selection term for the first stage regression and $e_{i t}$ is an idiosyncratic error term. I finally introduce sector fixed effects $v_{j}$ to control for time-unvarying heterogeneity among sectors and add year fixed effects $v_{t}$ to capture firms macroeconomic environment.

Table 10 and 11 report the results of the two stage estimation for cash and investment credit constraints, respectively. Regarding the first stage regression, columns (1) of both tables indicate that higher financial strength indicators reduce the firm probability to ask for a loan, while the larger the firm, the lower the demand for credit. In terms of the exclusion restriction, the variables trade credit ratio (i.e the sum of trade credit over total assets of the firm) and investment rate (i.e. the annual increase in gross fixed assets over the value added of the firm) are included in cash and investment credit demand models, respectively, but excluded from the rest of the exercises. The rationale for using these particular variables as instruments for demand is the following. Firms with higher trade credit are likely to have a higher need for cash credit to finance working capital (Gobbi \& Sette, 2013), but it is unlikely that credit decisions will be correlated with the level of trade credit without comparing it to current assets in order to asses the firm ability to repay its short-term liability ${ }^{19}$. Analogously, having a high investment rate is likely a signal for external financial needs (Gobbi \& Sette, 2013). These considerations make both variables good firm demand shifters. The latter are

$\overline{19}$ One should note that the effect of trade credit on loan demand is ambiguous as trade credit can be seen as a substitute for bank credit. 
very positively correlated with the demand for bank credit, and their effects are statistically significant at the $1 \%$ level.

Turning to the determinants of cash and investment credit constraints, columns (2) of Table 10 and 11 show thats solvency, cash flow, cash holdings and firm age are strongly significant and with the expected signs, indicating that they indeed play a role into the decision of a bank to grant cash/investment credit or not. Besides the size of the firm is also statistically significant and negative, but only for cash credit. The coefficients of the estimated probit can be used to compute the predicted index of cash credit constraints (henceforth ICCC) and index of investment credit constraints (henceforth IICC). These scores are defined at the firm level, which vary across time. Importantly, these two scores cannot be directly interpreted but can be used in order to rank firms, from the less to the more financially constrained. Based on the estimated coefficients of the Heckman probit analysis, the ICC scores are defined as:

$$
\begin{gathered}
\text { ICC }_{\text {score }}=-1.345 \cdot \text { Capital ratio }-2.622 \cdot \text { Cash ratio }-3.774 \cdot \text { Cash flow ratio } \\
-0.116 \cdot \text { Ln }(\text { total assets })-0.122 \cdot \text { Age } \\
\text { IIC } C_{\text {score }}=-1.108 \cdot \text { Capital ratio }-1.068 \cdot \text { Cash ratio }-1.209 \cdot \text { Cash flow ratio } \\
-0.091 \cdot \text { Age }
\end{gathered}
$$

The key step is to select those firms which can be considered as cash or investment credit constrained. The underlying idea is to calibrate a threshold over the ICCC and IICC scores distributions using the information from the survey data. Looking at the distribution of the ICCC and IICC scores, I then select the top $\mathrm{x} \%$ of the distribution of the ICCC and IICC scores by year, where $\mathrm{x}$ is the yearly average number of constrained firms over 2012-2016, directly extracted from the survey (Table 1). Finally, for each year, short-term (resp. longterm) constrained firms are identified as those with a value of the ICCC (resp. IICC) score 
greater than the empirical threshold. The ICCC and IICC indicators will be equal to 1 for them and zero otherwise.

Interestingly, the convenience of the procedure based on financial statements is that it can also be used to extrapolate the percentage of financially constrained firms that do not necessarily ask for a loan over the period 2012-2016. Above all, in contrast with the existing time-varying measures of financial constraints that rely on book-to-market, Tobin's Q or dividend payout (Kaplan \& Zingales, 1997; Whited \& Wu, 2006), the ICCC and IICCC can be extrapolated to every unquoted SMEs and circumvents the usual criticism related to the choices of single a-priori indicators (Musso \& Schiavo, 2008).

\subsection{The dynamic investment model}

Once the indicators of cash and investment credit constraints are obtained, I'm now able to gauge their effects on corporate investment for the whole sample of independent firms taken from the survey. Given that lagged values of investment are likely to determine, at least partially, the current level of investment, I consider a dynamic investment regression model where sales growth and cash flow control for investment opportunities ${ }^{20}$ I end up with 5,652 independent firms for which I have exhaustive financial information since 2012. My baseline specification can be represented by the following equation:

$$
\frac{I_{i t}}{A_{i t-1}}=\beta_{1} \frac{I_{i t-1}}{A_{i t-2}}+\beta_{2} \frac{C F_{i t}}{A_{i t-1}}+\beta_{3} \Delta S_{i t}+\beta_{4} \text { Uncertainty }_{j t}+\beta_{5} \text { ICC }_{i t}+v_{i}+v_{t}+e_{i t}
$$

Where $I$ denotes the firm's investment ; $A_{i t-1}$ its beginning-of-year total assets $; C F_{i t}$, its cash flow ; $\Delta S_{i t}$, its sales growth, Uncertainty $_{j t}$ is a sector-specific uncertainty measure based on the dispersion of firms' ROA (net income over total assets of the firm) within a given sector ${ }_{j}$ and a year ${ }_{t}$ Bloom et al. 2007 ${ }^{21}$, ICC is the Index of Credit Constraints defined previously

20 The interpretation of cash flow is controversial in the literature. See the work of Fazzari et al. (1988) and Kaplan \& Zingales (1997) for more details.

21 Note that the sector classification builds on the Nace Rev. 2 classification of the European Community. 
according to cash or investment credit; $v_{i}$ is an individual-specific fixed effect; $v_{t}$ is a yearspecific fixed effects and $e_{i t}$ is the idiosyncratic error term. The subscript $i$ and $j$ index firms and sectors while $t$ indexes year, where $\mathrm{t}=2012-2016$. Table 12 shows descriptive statistics of the above variables.

With such a model both the pooled and fixed effects estimator are likely to suffer from a dynamic panel bias (Nickell, 1981). I implement a dynamic panel methodology that relies on the Generalized-Method of Moments (GMM) following Arellano \& Bover (1995) and Blundell \& Bond (1998) and refined by Blundell et al. (2001). The GMM method can be applied when: (1) $\mathrm{N}$ is large but $\mathrm{T}$ is small; (2) the explanatory variables are endogenous and (3) unobserved firm-specific effects are correlated with other regressors (Roodman, 2006). This GMM estimator is called the system-GMM estimator since it combines, in a system, the regression in differences with the regression in levels ${ }^{22}$. The instruments for the equation in differences are the lagged exogenous variables (the environmental controls) and the lagged values of the potential endogenous variables. The instruments for the equation in levels are the lagged differences of the corresponding variables. In this framework, exogenous time dummies and business climate are instrumented by themselves. These are appropriate instruments under the following additional assumption: although there may be correlation between the levels of the right-hand side variables, there is no correlation between the differences of these variables and the firm-specific effect. More Specifically, I can rewrite a more general version of Eq. (1) as follows:

$$
Y_{i t}=\alpha Y_{i t-1}+\beta^{\prime} X_{i t}+v_{i}+v_{t}+e_{i t}
$$

22 In dynamic panel data where the observations are highly autoregressive an the number of time series is small, the standard GMM estimator has been found to have large finite sample bias and poor precision in simulation studies. The weak performance of the standard GMM panel data estimator is also frequent in relatively short panels with highly persistent data where lagged endogenous variables are weak instruments. Hence, the system-GMM estimator improves the performances of the standard GMM (Blundell et al. 2001).

23 Estimation is implemented in Stata using Roodman's xtabond2 package in which I use two lags of instruments and collapse the instrument matrix, see Roodman (2006). 
Where $Y$ is the investment scaled by beginning-of-year total assets, and $X$, my set of explanatory variables (including ICC, sales Growth and cash flow but excluding the lagged dependent variable); $v_{i}$ denotes a firm-specific component (encompassing the firm unobserved time-invariant heterogeneity); $v_{t}$ represents a time-specific component (that I account for by including time dummies in all my specifications); and eit is an idiosyncratic component.

The GMM panel estimator relies on first-differencing the estimating equation to eliminate the firm-specific fixed effect, and uses appropriate lags of the right-hand side variables as instruments. As can be seen from the following equation, first-differencing (2) allows us to eliminate the firm-specific effect $v_{i}$ :

$$
\begin{gathered}
Y_{i t}-Y_{i t-1}=\alpha\left(Y_{i t-1}-Y_{i t-2}\right)+\beta^{\prime}\left(X_{i t}-X_{i t-1}\right) \\
+\left(v_{t}-v_{t-1}\right)+\left(e_{i t}-e_{i t-1}\right)
\end{gathered}
$$

The use of appropriate instruments is necessary to deal with the likely endogeneity of the explanatory variables, and also to deal with the fact that the new error term $e_{i t}-e_{i t-1}$ is correlated with the lagged dependent variable. Consistency of the GMM estimates depends on the validity of the instruments. I test for the validity of my instruments by using two tests suggested by Arellano \& Bond (1991): the J-test and the test for second-order serial correlation of the residuals (m2). The former is the Sargan test for overidentifying restrictions, asymptotically distributed as a $\chi^{2}$ with degrees of freedom equal to the number of instruments less the number of parameters, under the null of instrument validity. The $\mathrm{m} 2$ test is asymptotically distributed as a standard normal under the null of no second-order serial correlation, and provides a further check on the specification of the model and on the legitimacy of variables dated $\mathrm{t}-2$ as instruments.

\subsection{Results}

Table 13 shows the results of the dynamic panel data estimation regarding short-term credit constraints. Across all specifications, the values of the J-test and the test for second- 
order serial correlation of the residuals suggest that the instruments employed are appropriate. Focusing on tangible assets only, the first column presents the estimation of equation 5. In the latter, the lagged investment, the cash flow ratio and the turnover growth rate are significant and positive ${ }^{24}$. In this regard, the statistical significance of the lagged investment to total assets ratio emphasizes the importance of accounting for endogeneity when analyzing determinants of corporate investment. In contrast, the sectoral uncertainty is not significant. Incorporating both tangible and intangible assets in column (2), my baseline specification, the same results are found.

Regarding the main focus of the analysis, the index of cash credit constraints (ICCC) turns out to be negative and significant for all specifications, indicating that short-term credit constraints matter for corporate investment (H1): a cash credit constrained firms decreases its investment to total assets ratio by around 40 basis points in column (2). Lower than my previous results using a non-parametric matching approach, this pattern still suggests that the working capital channel is playing a essential role. Thus, switching to relative change, as the average average investment (all fixed assets) to total assets ratio equals $3.3 \%$, the estimated semi-elasticities amounts to decrease of $12 \%$.

Looking at the mechanism at play, column (3) introduces the annual increase in working capital scaled by the beginning-of-year total assets of the firm . Interacting this variable with the ICCC, the specification reveals that the higher the working capital needs, the more cash credit constraints are detrimental to firm investment (H2). Hence, when a cash credit constraint is binding, working capital needs competes with investments in fixed assets. What is more, the annual increase in working capital has a positive and significant coefficient which is higher that one related to the interaction term, thus showing that the negative relationship between working capital and fixed investment only holds for short-term financial frictions (H3).

24 Consistent with (Bond, 2002), note that the coefficient on lagged investment is in the range between the OLS and FE estimates (results not reported but available upon request). 
Do liquid firms are able to make up for a lack of short-term finance? To address this issue, column (4) incorporates the cash and the gross working capital ratios as measures of firms' liquidity. While the interaction coefficient between the cash ratio and the ICCC appears not significant, the interaction between the ICCC and the gross working capital turns out to be positive and significant, showing that the deleterious effect of cash credit constraints is lower for liquid firms (H4). This result is consistent with previous work that finds smoothing benefits of current assets (Fazzari \& Petersen, 1993; Almeida et al., 2004; Duchin et al., 2010 25 Finally, in column (6), I interact the ICCC with the cash flow ratio to see whether the investment cash flow sensitivity hypothesis (Fazzari et al., 1988) is verified for cash credit. I find no significant effects.

Let's now focus on investment credit constraints. Table 14 exploits the same specifications than Table 13. Overall, instruments can be considered as valid and results are very similar : the lagged investment, the cash flow ratio and the turnover growth rate are significant and positive and very close to my previous findings in the benchmark specification (i.e. column (2)). Furthermore, long-term credit constraints also negatively affect capital accumulation insofar as the index of investment credit constraints (IICC) appears negative and significant for all specifications. Interestingly, the detrimental effect of long term credit constraints is slightly higher than cash credit ones : an investment credit constrained firms decreases its investment to total assets ratio by around 50 basis points in column (2) and the estimated semi-elasticities equals $14 \%$.

However, a first major difference stands out in column (3): the coefficient on the interaction between the IICC and the annual increase in working capital is no more significant, thus strongly supporting the working capital channel hypothesis. Besides, the annual increase in working capital alone is still positive and significant which shows, once again, that working capital needs is still a proxy for investment opportunities in the absence of financial constraints. The second salient result comes with column (4) in which the interaction term is

$\overline{25}$ Note that I also use all current assets as an alternative measure of liquidity and find similar results. 
no more significant. Hence, the edging role of current assets turns out to be only associated with short-term credit constraints. As for column (5), as is the case for cash credit, I find no differential effects of cash flow on capital accumulation according to long-term credit constraints.

\section{Robustness}

In this section, I perform a number of robustness checks with respect to the two alternative empirical approaches I use. First, my non-parametric analysis is challenged with a propensity score matching. The effect of life cycle differences are taken into account and quantile regressions are implemented to control for lumpy investments. Second, the dynamic panel results are supplemented by the use of alternative measures of investment opportunities and the inclusion of other instruments such as leverage.

\subsection{Propensity score matching}

In the matching set-up I use, the Abadie-Imbens estimator requires exact matches for constrained and unconstrained firms in every sector and year. Althought I'm not fully concerned with the "curse of dimensionality" arising in the presence of exact matching on a large set of variables, I can still use propensity score matching (Rosenbaum \& Rubin, 1983) to increase the size of my sample. To do so, I implement the estimator proposed by Dehejia \& Wahba (2002), which uses observed characteristics as inputs in a probit regression determining whether the firm is financially constrained. ${ }^{26}$ Once firms are projected in this propensity score space, for each constrained firm, the procedure looks for the nearest unconstrained match. After partitioning the propensity score vector into different category, it is checked whether the constrained and unconstrained firms in each category have the same average propensity score. Importantly, the overlap tests also ensure that firms that are matched in the same propensity categories also have similar averages of the covariates in the probit I apply the nearest neighbor matching estimator implemented in Becker et al. (2002) imposing the common
support condition and using bootstrapped errors. 
estimation. Once assignment to treatment is determined in this way, I'm able to measure the average treatment effect on corporate outcomes of constrained and unconstrained firms in the same vein as the Abadie-Imbens matching.

Columns (1) and (2) of Table 9 report the results associated with this alternative matching estimator. The propensity score estimator confirms that both cash and investment credit constraints reduce significantly the investment to total assets ratio. The new results are even more striking for short-term credit constraints as the average difference in annual increase in both tangible and intangible investment between treated and their controls reaches 1.4 percentage point of total assets.

\subsection{Life cycle difference}

Differences in life cycle or age could potentially produce differences in corporate investment. For instance, firms may invest less in fixed assets with regard to their total assets at the beginning of their life cycle. If credit constrained firms were systematically less mature than unconstrained ones, such life cycle effects could explain my results. To investigate this issue, I use a dummy that takes the values $0,1,2$ and 3 whether firm age belongs to the first, the second, the third an the last quartile of the distribution, respectively. Accordingly, I now match firms on three categorical variables (sector, year and age) and five continuous variables.

Columns (3) and (4) of Table 9 report the results. Matching on age in addition to size and industry yields similar results, with an estimated difference in corporate investment of -0.011 and -0.015 for cash and investment credit constraints, respectively. These point estimates are

slightly higher than my baseline estimate of -0.009 for both types of credit constraints. This findings suggest that life cycle differences play a limited role in explaining the differences in investment behavior between credit constrained firms and their counterfactuals.

\subsection{Quantile regressions}

One other concern may stem from lumpy investment decisions (Doms \& Dunne, 1998; Caballero \& Engel, 1999). In the presence of important fixed costs related to equipment 
installations, firms are likely to invest sequentially so that investment decisions depend on an optimal level of capital. In this context, differences in average investment level between credit constrained firms and their controls could be driven by outliers ${ }^{27}$. To control for this possibility, table 16 presents quantile regressions that allows to compare gross investment in fixed assets for financially constrained and unconstrained firms at different points in their respective distributions (i.e. the first quartile, the median and the last quartile). More specifically, the latter hinges on the sample of treated (i.e. constrained firms) and controls firms obtained previously in Panel B of table 8. Overall, holding cash flow and investment opportunities constant, the negative effects of cash and investment credit constraints on investment are confirmed all along the distribution of investment to total assets ratio. Yet, those effects are increasing in the right tail of the distribution.

\subsection{Additional instruments and alternative measures of investment opportunities}

In Table 17, I introduce additional regressors in the benchmark specification. First, I make use of the firm's net worth (i.e. the sum of own funds over total assets of the firm) to assess whether over-indebtedness matters for corporate investment decisions. On the one hand, over-indebtedness may force firms to allocate additional cash-flow to reimburse its creditors, thus lowering internal finance devoted to Investment. On the other, over-indebted firms may suffer from tougher access to finance that is likely to weaken its investment choices. In this regard, it seems reasonable to assume that changes in a firm's indebtedness affect its investment decisions only when the indebtedness is already high, that is when the debt is getting close to some possible "maximum level". Hence, I construct a dummy variable "Highly leveraged" that takes the value 1 whether the firm can be considered as under-capitalized or highly-leveraged (i.e. whose the firm capital ratio belongs to the first quartile of the distribution). Interestingly, column (1) and (2) indicate that over-indebtedness significantly reduce firm's capital accumulation, without changing the significance of coefficients associated with

\footnotetext{
27 Yet, as outlined previously, all measures of investment, along with all other continuous variables are winsorized at the top and bottom first percentile.
} 
ICCC and IICC.

Turning to the investment opportunities bias related to the investment-cash flow sensitivity literature (Gilchrist \& Himmelberg, 1995; Erickson \& Whited, 2000; Bond, 2002; Cummins et al. 2006), I test whether my results are sensitive to alternative definitions of investment opportunities. In columns (3) and (4), I use the marginal Q measure implemented by D'Espallier $\&$ Guariglia (2015) and Mulier et al. (2016). 28. In addition, in columns (5) and (6), I also use the industry-level Growth in Gross Value Added (GGAV) as an alternative proxy of investment opportunities (D'Espallier \& Guariglia, 2015). Overall, the main results hold when I use these measures instead of the turnover growth rate. Finally, in the same vein as Fazzari et al. (1988), I also control for two additional lags of cash flow and investment opportunities but none of these lags appear significant in the specifications 29 .

\section{Conclusion and policy implication}

In this paper I investigate the real effects of short-term financial constraints through an under-explored transmission mechanism between the financial and the real sectors. While the bulk of research on the real effect of financial constraints focuses on long-term liabilities, my results stress the importance of also considering firms' need to finance their working capital.

Making use of qualitative survey data on the access to finance of almost 8,000 independent SMEs, I implement both matching estimator techniques and dynamic panel specifications to assess the effect of short-term financial constraints on corporate investment. All in all, I find that short-term credit constraints are at least as important as long-term ones for SMEs' investment decisions. In the presence of cash credit constraints, working capital needs compete with fixed investment to the extent that liquid assets such as accounts receivable and

28 Given the lack of market data available for unquoted SMEs, traditional variables such as Tobin's Q or Fundamental Q cannot be computed. Following Honda \& Suzuki (2000), D’Espallier \& Guariglia (2015) developed an accounting proxy for marginal $\mathrm{Q}$ to control for investment opportunities. Their marginal $\mathrm{Q}$ is defined as the ratio of profit per unit of capital over the cost of capital.

29 Results are not presented but available upon request. 
inventories cannot be monetized so easily. Hence, cash credit constraints may force SMEs to forgo investment opportunities in order to finance their working capital needs.

Importantly, the detrimental effect of short-term credit constraints on corporate investment is stronger for firms with higher working capital needs, while the negative relationship between working capital and fixed investment is found to be associated with short-term financial frictions. In the end, only highly liquid firms are able to partially offset the impact of short-term financial constraints on fixed investment by monetizing their current assets.

Although short-term credit constrained firms represent a narrow subset of my data, they are representative of a broader range of highly bank-dependent firms outside my sample that are smaller in size and account for a significant share of output. Thus, the working capital channel is likely to have potentially important macroeconomic implications for the real effects of financial frictions. Above all, it raises the importance of short-term finance for SMEs and calls for more public credit guarantees oriented towards working capital needs to foster longterm investment and economic growth. 


\section{References}

Abadie, A., Drukker, D., Herr, J. L., Imbens, G. W. et al. (2004). Implementing matching estimators for average treatment effects in stata. Stata Journal, 4, 290-311.

Abadie, A., \& Imbens, G. W. (2006). Large sample properties of matching estimators for average treatment effects. Econometrica, 74, 235-267.

Aghion, P., Askenazy, P., Berman, N., Cette, G., \& Eymard, L. (2012). Credit constraints and the cyclicality of $\mathrm{r} \& \mathrm{~d}$ investment: Evidence from france. Journal of the European Economic Association, 10, 1001-1024.

Almeida, H., \& Campello, M. (2007). Financial constraints, asset tangibility, and corporate investment. The Review of Financial Studies, 20, 1429-1460.

Almeida, H., Campello, M., Laranjeira, B., \& Weisbenner, S. (2012). Corporate debt maturity and the real effects of the 2007 credit crisis. Technical Report.

Almeida, H., Campello, M., \& Weisbach, M. S. (2004). The cash flow sensitivity of cash. The Journal of Finance, 59, 1777-1804.

Almeida, H., Carvalho, D., \& Kim, T. (2017). Understanding the credit multiplier: The working capital channel, .

Arellano, M., \& Bond, S. (1991). Some tests of specification for panel data: Monte carlo evidence and an application to employment equations. The Review of Economic Studies, $58,277-297$.

Arellano, M., \& Bover, O. (1995). Another look at the instrumental variable estimation of error-components models. Journal of Econometrics, 68, 29-51.

Asker, J., Farre-Mensa, J., \& Ljungqvist, A. (2014). Corporate investment and stock market listing: A puzzle? The Review of Financial Studies, 28, 342-390. 
Becker, S. O., Ichino, A. et al. (2002). Estimation of average treatment effects based on propensity scores. The Stata Journal, 2, 358-377.

Bernanke, B. S., \& Gertler, M. (1989). Agency costs, collateral, and business fluctuations.

Bloom, N., Bond, S., \& Van Reenen, J. (2007). Uncertainty and investment dynamics. The review of economic studies, 74, 391-415.

Blundell, R., \& Bond, S. (1998). Initial conditions and moment restrictions in dynamic panel data models. Journal of Econometrics, 87, 115-143.

Blundell, R., Bond, S., \& Windmeijer, F. (2001). Estimation in dynamic panel data models: improving on the performance of the standard gmm estimator. In Nonstationary panels, panel cointegration, and dynamic panels (pp. 53-91). Emerald Group Publishing Limited.

Bond, S. R. (2002). Dynamic panel data models: a guide to micro data methods and practice. Portuguese Economic Journal, 1, 141-162.

Caballero, R. J., \& Engel, E. M. (1999). Explaining investment dynamics in us manufacturing: a generalized (s, s) approach. Econometrica, 67, 783-826.

Campello, M., Graham, J. R., \& Harvey, C. R. (2010). The real effects of financial constraints: Evidence from a financial crisis. Journal of Financial Economics, 97, 470-487.

Christiano, L. J., Eichenbaum, M., \& Evans, C. L. (2005). Nominal rigidities and the dynamic effects of a shock to monetary policy. Journal of Political Economy, 113, 1-45.

Cleary, S. (1999). The relationship between firm investment and financial status. The Journal of Finance, 54, 673-692.

Cleary, S. (2006). International corporate investment and the relationships between financial constraint measures. Journal of Banking $\mathcal{F}$ Finance, 30, 1559-1580. 
Cummins, J. G., Hassett, K. A., \& Oliner, S. D. (2006). Investment behavior, observable expectations, and internal funds. American Economic Review, 96, 796-810.

Dehejia, R. H., \& Wahba, S. (2002). Propensity score-matching methods for nonexperimental causal studies. Review of Economics and Statistics, 84, 151-161.

D'Espallier, B., \& Guariglia, A. (2015). Does the investment opportunities bias affect the investment-cash flow sensitivities of unlisted smes? The European journal of finance, 21, $1-25$.

Doms, M., \& Dunne, T. (1998). Capital adjustment patterns in manufacturing plants. Review of Economic Dynamics, 1, 409-429.

Duchin, R., Ozbas, O., \& Sensoy, B. A. (2010). Costly external finance, corporate investment, and the subprime mortgage credit crisis. Journal of Financial Economics, 97, 418-435.

Erickson, T., \& Whited, T. M. (2000). Measurement error and the relationship between investment and q. Journal of Political Economy, 108, 1027-1057.

Farre-Mensa, J., \& Ljungqvist, A. (2016). Do measures of financial constraints measure financial constraints? The Review of Financial Studies, 29, 271-308.

Fazzari, S., Hubbard, R. G., \& Petersen, B. C. (1988). Financing constraints and corporate investment. Brooking Papers on Economic Activity, 1, 141-195.

Fazzari, S. M., \& Petersen, B. C. (1993). Working capital and fixed investment: new evidence on financing constraints. The RAND Journal of Economics, (pp. 328-342).

Ferrando, A., Blank, S., Neugebauer, K., Siedschlag, I., Iudice, M., Altomonte, C., Felt, M.-H., \& Meinen, P. (2015). Assessing the financial and financing conditions of firms in europe: the financial module in compnet, .

Ferrando, A., \& Mulier, K. (2015). Firms' financing constraints: Do perceptions match the actual situation? The Economic and Social Review, 46, 87-117. 
Gertler, M., \& Gilchrist, S. (1994). Monetary policy, business cycles, and the behavior of small manufacturing firms. The Quarterly Journal of Economics, 109, 309-340.

Gilchrist, S., \& Himmelberg, C. P. (1995). Evidence on the role of cash flow for investment. Journal of Monetary Economics, 36, 541-572.

Gobbi, G., \& Sette, E. (2013). Do firms benefit from concentrating their borrowing? evidence from the great recession. Review of Finance, 18, 527-560.

Heckman, J. J. (1979). Sample selection bias as a specification error (with an application to the estimation of labor supply functions).

Holmstrom, B., \& Tirole, J. (1997). Financial intermediation, loanable funds, and the real sector. the Quarterly Journal of Economics, 112, 663-691.

Honda, Y., \& Suzuki, K. (2000). Estimation of the investment thresholds of large japanese manufacturers. The Japanese Economic Review, 51, 473-491.

Hoshi, T., Kashyap, A., \& Scharfstein, D. (1991). Corporate structure, liquidity, and investment: Evidence from japanese industrial groups. The Quarterly Journal of Economics, $106,33-60$.

Imbens, G. W. (2004). Nonparametric estimation of average treatment effects under exogeneity: A review. Review of Economics and Statistics, 86, 4-29.

Jermann, U., \& Quadrini, V. (2012). Macroeconomic effects of financial shocks. American Economic Review, 102, 238-71.

Jiménez, G., Ongena, S., Peydró, J.-L., \& Saurina, J. (2012). Credit supply and monetary policy: Identifying the bank balance-sheet channel with loan applications. American Economic Review, 102, 2301-26. 
Kadapakkam, P.-R., Kumar, P., \& Riddick, L. A. (1998). The impact of cash flows and firm size on investment: The international evidence. Journal of Banking $\mathcal{F}$ Finance, 22, 293-320.

Kahle, K. M., \& Stulz, R. M. (2013). Access to capital, investment, and the financial crisis. Journal of Financial Economics, 110, 280-299.

Kaplan, S. N., \& Zingales, L. (1997). Do investment-cash flow sensitivities provide useful measures of financing constraints? The Quarterly Journal of Economics, 112, 169-215.

Kiyotaki, N., \& Moore, J. (1997). Credit cycles. Journal of Political Economy, 105, 211-248.

Kremp, É., \& Sevestre, P. (2000). L'appartenance à un groupe facilite le financement des entreprises, .

Kremp, E., \& Sevestre, P. (2013). Did the crisis induce credit rationing for french smes? Journal of Banking E Finance, 37, 3757-3772.

Lamont, O., Polk, C., \& Saaá-Requejo, J. (2001). Financial constraints and stock returns. The Review of Financial Studies, 14, 529-554.

Lemmon, M., \& Roberts, M. R. (2010). The response of corporate financing and investment to changes in the supply of credit. Journal of Financial and Quantitative Analysis, 45, $555-587$.

Lucas Jr, R. E. (1967). Adjustment costs and the theory of supply. Journal of Political Economy, 75, 321-334.

Mendoza, E. G. (2010). Sudden stops, financial crises, and leverage. American Economic Review, 100, 1941-66.

Michaely, R., \& Roberts, M. R. (2011). Corporate dividend policies: Lessons from private firms. The Review of Financial Studies, 25, 711-746. 
Mulier, K., Schoors, K., \& Merlevede, B. (2016). Investment-cash flow sensitivity and financial constraints: Evidence from unquoted european smes. Journal of Banking $\mathcal{F}$ Finance, $73,182-197$.

Musso, P., \& Schiavo, S. (2008). The impact of financial constraints on firm survival and growth. Journal of Evolutionary Economics, 18, 135-149.

Myers, S. C., \& Majluf, N. S. (1984). Corporate financing and investment decisions when firms have information that investors do not have. Journal of Financial Economics, 13, $187-221$.

Nickell, S. (1981). Biases in dynamic models with fixed effects. Econometrica: Journal of the Econometric Society, (pp. 1417-1426).

Popov, A., \& Udell, G. F. (2012). Cross-border banking, credit access, and the financial crisis. Journal of International Economics, 87, 147-161.

Roodman, D. (2006). How to do xtabond2: an introduction to 'difference'and 'system. In GMM in STATA', Center for Global Development Working Paper No. 103. Citeseer.

Rosenbaum, P. R., \& Rubin, D. B. (1983). The central role of the propensity score in observational studies for causal effects. Biometrika, 70, 41-55.

Smith, A. (1776). An inquiry into the nature and causes of the wealth of nations (ed. RH Campbell, AS Skinner, and WB Todd).

Whited, T. M., \& Wu, G. (2006). Financial constraints risk. The Review of Financial Studies, $19,531-559$. 
Figure 1: Importance of working capital and trade credit according to firm size

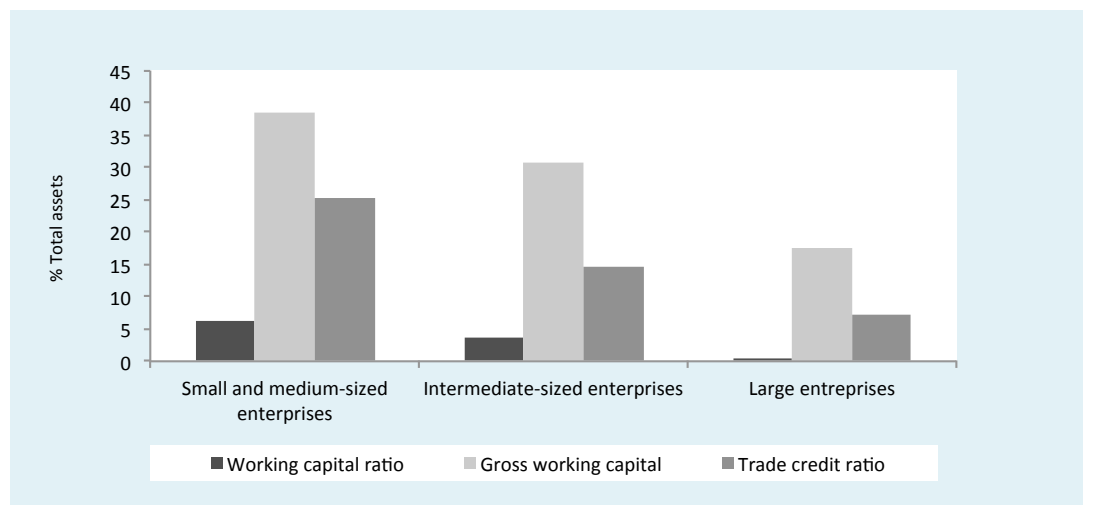

Notes: All the definitions of the variables are summarized in Table 2 The category small and medium-sized enterprises (SME) is made up of enterprises that employ fewer than 250 people and have an annual turnover of less than 50 million euro or a balance sheet total not exceeding 43 million euro. The category intermediate-sized enterprise (ETI) refers to companies with between 250 and 4999 employees, and a turnover which does not exceed 1.5 billion euros or a balance sheet total which does not exceed 2 billion euros. The category Large enterprises stands for enterprise that has at least 5000 employees and an annual turnover greater than 1.5 billion euros or a balance sheet total of more than 2 billion euros. Based on the year 2016, calculations are made using the FIBEN database (Banque de France).

Figure 2: Importance of SMEs' working capital and trade credit according to sectors

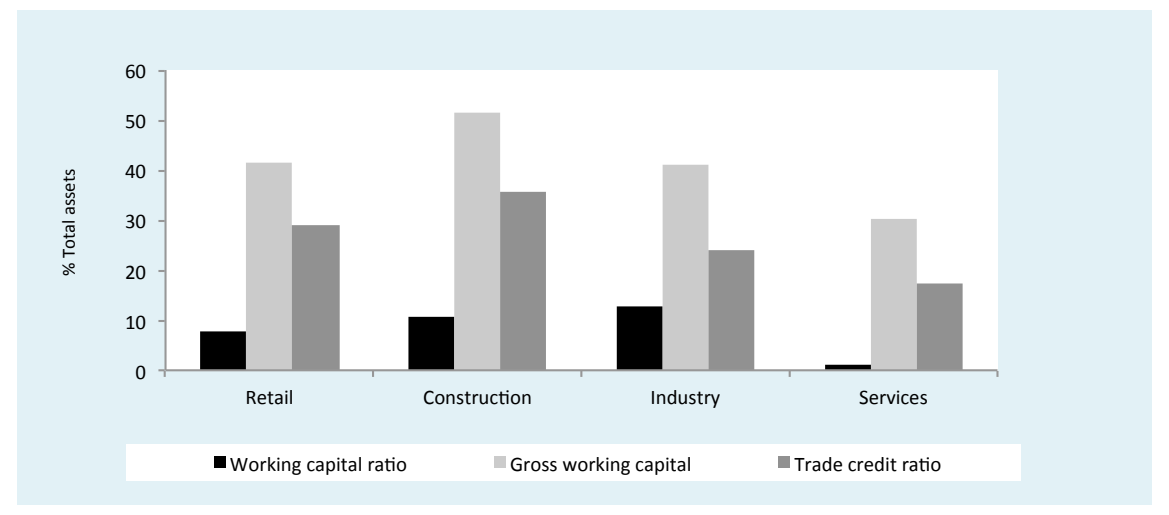

Notes: All the definitions of the variables are summarized in Table 2 The industry classification taxonomy comes from the statistical classification of economic activites in the European Community (NACE Rev.2). Based on the year 2016, calculations are made using the FIBEN database (Banque de France). 
Figure 3: Diagram of the working capital channel

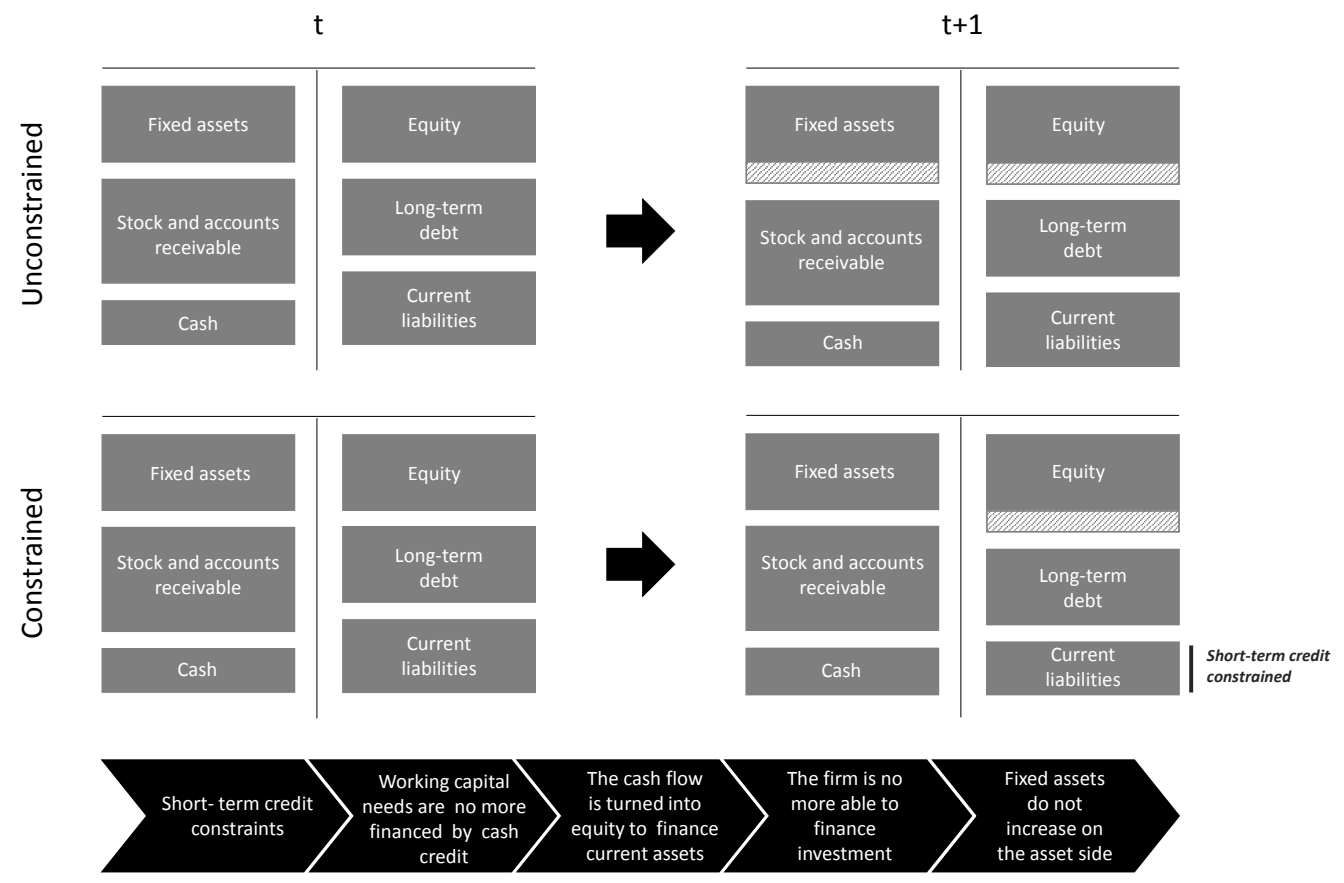

Interpretation: while in time $t$ no firms are credit constrained, in time $t+1$ constrained firms become short-term credit constrained and their current liabilities decrease. Hence, their working capital needs are no more financed by cash credit and short-term credit constrained firms are forced to turn their cash-flow into equity to finance their currents assets, thus maintaining the same balance sheet size. In contrast, firms which are not short-term credit constrained are able to turn their cash-flow into fixed assets to increase their balance sheet. 
Table 1: Yearly credit constrained firms over 2012-2016

\begin{tabular}{lllllll}
\hline Year & 2012 & 2013 & 2014 & 2015 & 2016 & All sample \\
\hline Short-term credit constrained & $18 \%$ & $16.92 \%$ & $13.18 \%$ & $12.26 \%$ & $8.06 \%$ & $13.30 \%$ \\
Long-term credit constrained & $6.08 \%$ & $6.20 \%$ & $5.49 \%$ & $4.16 \%$ & $3.15 \%$ & $4.84 \%$ \\
\hline \hline
\end{tabular}

Notes: The table reports the percentage of yearly short-term (resp. long-term) credit constrained firms over 2012-2016, out of firms that exhibit a yearly positive demand for cash loans (resp. investment loans). Credit constrained refers to firms that declare themselves as credit constrained as explained in section 3 .

Table 2: Variables definitions

\begin{tabular}{|c|c|}
\hline Variable & Definition \\
\hline Capital ratio & The ratio of own funds over total assets of the firm. \\
\hline Cash ratio & The ratio of cash holdings over total assets of the firm. \\
\hline Cash flow ratio & The ratio of cash flow over total assets of the firm. \\
\hline Age & The number of years since funding. \\
\hline Ln(total assets) & The log of the total assets of the firm. \\
\hline$\Delta S_{i t}$ & The annual percentage increase in sales: $S_{i t} / S_{i t-1-1}$. \\
\hline$I_{i t} / A_{i t-1}($ tangible $)$ & $\begin{array}{l}\text { The annual increase in gross tangible fixed assets (i.e. property, plants } \\
\text { and equipment) scaled by beginning-of-year total assets. }\end{array}$ \\
\hline$I_{i t} / A_{i t-1}$ (all fixed assets) & $\begin{array}{l}\text { The annual increase in both gross tangible (i.e. property, plants and } \\
\text { equipment) and intangible (i.e. patents, copyrights, trademarks and } \\
\text { franchises) fixed assets scaled by beginning-of-year total assets. }\end{array}$ \\
\hline Investment rate & The ratio of all fixed assets investment over the value added of the firm. \\
\hline Trade credit ratio & The ratio of accounts payable over total assets of the firm. \\
\hline Business climate & $\begin{array}{l}\text { The business climate indicator summarizes the mood of the French } \\
\text { short-term economic surveys according to four main sectors (industry, } \\
\text { services, construction and retail): the higher it is, the more positive the } \\
\text { view firms have of the economic outlook. It is computed by the French } \\
\text { national institute for statistical and economic studies (INSEE). }\end{array}$ \\
\hline Working capital needs & $\begin{array}{l}\text { The sum of accounts receivables and inventories minus accounts } \\
\text { payable and other non-financial debt due in less than one year. }\end{array}$ \\
\hline Working capital ratio & The ratio of working capital needs over total assets of the firm. \\
\hline Gross working capital ratio & $\begin{array}{l}\text { The sum of accounts receivables and inventories over total assets of } \\
\text { the firm. }\end{array}$ \\
\hline$\Delta W / A_{i t-1}$ & $\begin{array}{l}\text { The annual increase in working capital needs scaled by beginning-of-yea } \\
\text { total assets. }\end{array}$ \\
\hline ICCC & $\begin{array}{l}\text { The Index of Cash Credit Constraint. The ICCC defines firms that can be } \\
\text { considered as cash credit constrained using information derived } \\
\text { from their financial situation and their access to finance. See section } 5 \\
\text { for more details. }\end{array}$ \\
\hline IICC & $\begin{array}{l}\text { The Index of Investment Credit Constraint. The ICCC defines firms that } \\
\text { can be considered as investment credit constrained using information } \\
\text { derived from their financial situation and their access to finance. See } \\
\text { section } 5 \text { for more details. }\end{array}$ \\
\hline Uncertainty & $\begin{array}{l}\text { The dispersion of firms' ROA (net income over total assets of the firm) } \\
\text { within a given year and sector. }\end{array}$ \\
\hline
\end{tabular}




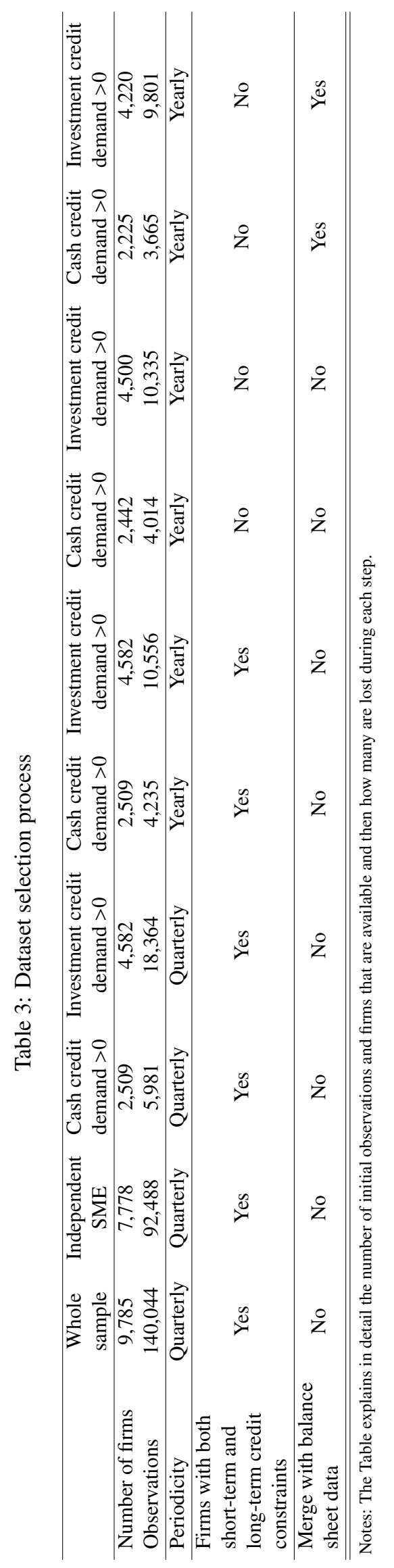


Table 4: Relationship between qualitative indicators of financial constraints and traditional measures

\begin{tabular}{lcccc}
\hline & Whited -Wu index & Kaplan-Zingales index & Hadlock-Pierce index & $\begin{array}{l}\text { Banque de France } \\
\text { speculative grade }\end{array}$ \\
\hline Short-term credit constrained & $0.013^{* *}$ & $0.001^{* *}$ & 0.055 & $1.668^{* * *}$ \\
& $(0.005)$ & $(0.001)$ & $(0.053)$ & $(0.104)$ \\
Long-term credit constrained & 0.001 & 0.001 & $0.106^{* *}$ & $1.702^{* * *}$ \\
& $(0.001)$ & $(0.001)$ & $(0.054)$ & $(0.936)$ \\
\hline
\end{tabular}

Notes: The table reports the estimation of a logit model in which traditionnal indicators of financial constraints are used to explain indicators of Short-term or long-term credit constraints. Credit constrained firms refer to firms that declare themselves as cash or investment credit constrained as explained in section 3 . $* * *$ indicates significance at the $1 \%$ level, $* *$ at the $5 \%$ level, and $*$ at the $10 \%$ level.

$\mathrm{WW}=-0.091 * \frac{C F}{T A}-0.044 * \ln (\mathrm{TA})+0.021 * \frac{\text { longtermdebt }}{T A}-0.035 *$ salesgrowth $+0.102 *$ industrysalesgrowth $-0.062 * \frac{\text { Dividends }}{T A}$

$\mathrm{KZ}=-1.001909 * \frac{C F}{T A}+3.139193 * \frac{\text { longtermdebt }}{T A}-1.314759 *$ cashratio $+0.2826389 *$ Marginal Q-39.36780* $\frac{\text { Dividends }}{T A}$

$\mathrm{HP}=-0.737 * \log (\mathrm{TA})+0.043 *(\log (\mathrm{TA}))^{2}-0.04 *$ age

Table 5: Firm Characteristics by applicant-group: median test

\begin{tabular}{|c|c|c|c|c|c|c|}
\hline & \multicolumn{3}{|c|}{ Short term credit } & \multicolumn{3}{|c|}{ Long term credit } \\
\hline Cash flow ratio ${ }_{t-1}$ & $\begin{array}{c}\text { Applicant }_{t} \\
4.86 \%\end{array}$ & $\begin{array}{c}\text { Non applicant } t \\
6.23 \%\end{array}$ & $\begin{array}{c}\text { Median-test } \\
0.00 * * *\end{array}$ & $\begin{array}{c}\text { Applicant }_{t} \\
6.53 \%\end{array}$ & $\begin{array}{c}\text { Non applicant } t \\
5.58 \%\end{array}$ & $\begin{array}{c}\text { Median-test } \\
0.00 * * *\end{array}$ \\
\hline Capital ratio ${ }_{t-1}$ & $23.07 \%$ & $28.68 \%$ & $0.00 * * *$ & $27.01 \%$ & $28.26 \%$ & $0.00 * * *$ \\
\hline Cash ratio $_{t-1}$ & $3.36 \%$ & $9.30 \%$ & $0.00 * * *$ & $7.33 \%$ & $8.55 \%$ & $0.00 * * *$ \\
\hline $\operatorname{Ln}(\text { total assets })_{t-1}$ & 9.07 & 8.58 & $0.00 * * *$ & 7.94 & 8.45 & $0.00 * * *$ \\
\hline $\mathrm{Age}_{t}$ & 28 & 28 & 0.48 & 29 & 29 & 0.00 \\
\hline Observations & 3,655 & 19,764 & & 9,801 & 13,596 & \\
\hline Firms & 2,225 & 6,718 & & 4,220 & 5,884 & \\
\hline
\end{tabular}

Notes: The table reports the median values of the variables split by applicant-group and the p-value associated with the test of the equality of the median between applicant observations and non-applicant observations. All the definitions of the variables are summarized in Table 2 *** indicates significance at the $1 \%$ level, $* *$ at the $5 \%$ level, and * at the $10 \%$ level. 
Table 6: Firm Characteristics by constraint-group: median test

\begin{tabular}{|c|c|c|c|c|c|c|}
\hline & \multicolumn{3}{|c|}{ Short term credit } & \multicolumn{3}{|c|}{ Long term credit } \\
\hline Cash flow ratio ${ }_{t-1}$ & $\begin{array}{c}\text { Constrained }_{t} \\
2.02 \%\end{array}$ & $\begin{array}{c}\text { Unconstrained }_{t} \\
5.18 \%\end{array}$ & $\begin{array}{c}\text { Median-test } \\
0.00^{* * *}\end{array}$ & $\begin{array}{c}\text { Constrained }_{t} \\
4.59 \%\end{array}$ & $\begin{array}{c}\text { Unconstrained }_{t} \\
6.86 \%\end{array}$ & $\begin{array}{c}\text { Median-test } \\
0.00 * * *\end{array}$ \\
\hline Capital ratio $_{t-1}$ & $16.08 \%$ & $23.96 \%$ & $0.00^{* * *}$ & $21.23 \%$ & $27.35 \%$ & $0.00 * * *$ \\
\hline Cash ratio ${ }_{t-1}$ & $2.13 \%$ & $3.69 \%$ & $0.00 * * *$ & $3.49 \%$ & $7.57 \%$ & $0.03 * * *$ \\
\hline $\mathrm{Ln}$ (total assets $)_{t-1}$ & 8.62 & 9.13 & $0.00 * * *$ & 8.94 & 8.95 & 0.60 \\
\hline $\mathrm{Age}_{t}$ & 26 & 28 & $0.04 * *$ & 27 & 29 & $0.02 * *$ \\
\hline Observations & 486 & 3,169 & & 474 & 9,327 & \\
\hline Firms & 392 & 1,997 & & 399 & 4,097 & \\
\hline
\end{tabular}

Notes: The table reports the median values of the variables split by constraint-group and the p-value associated with the test of the equality of the median between the constrained observations and the unconstrained observations. constrained firms refers to firms that declare themselves as cash or investment credit constrained as explained in section 3. All the definitions of the variables are summarized in Table 2. *** indicates significance at the $1 \%$ level, $* *$ at the $5 \%$ level, and * at the $10 \%$ level.

Table 7: Corporate investment by constraint-group: median test

\begin{tabular}{lccc|ccc}
\hline & \multicolumn{3}{c}{ Short term credit } & \multicolumn{3}{c}{ Long term credit } \\
\hline & Constrained $_{t}$ & Unconstrained $_{t}$ & Median-test & Constrained $_{t}$ & Unconstrained $_{t}$ & Median-test \\
$I_{i t} / A_{i t-1}$ (tangible) & $0.75 \%$ & $1.72 \%$ & $0.00^{* * *}$ & $1.47 \%$ & $2.30 \%$ & $0.00_{* * *}$ (all fixed assets) \\
$I_{i t} / A_{i t-1}$ (all & $0.94 \%$ & $1.96 \%$ & $0.00 * * *$ & $1.71 \%$ & $2.59 \%$ & $0.00_{* * *}$ \\
Observations & 486 & 3,169 & & 474 & 9,327 & \\
Firms & 392 & 1,997 & & 399 & 4,097 \\
\hline \hline
\end{tabular}

Notes: The table reports the median values of corporate investment (i.e. the annual change in gross fixed assets, either tangible or intangible, scaled by the beginning-of-year total assets) split by constraint-group and the p-value associated with the test of the equality of the median between the constrained observations and the unconstrained observations. constrained firms refers to firms that declare themselves as cash or investment credit constrained as explained in section 3 . All the definitions of the variables are summarized in Table $2 * * *$ indicates significance at the $1 \%$ level,** at the $5 \%$ level, and * at the $10 \%$ level. 


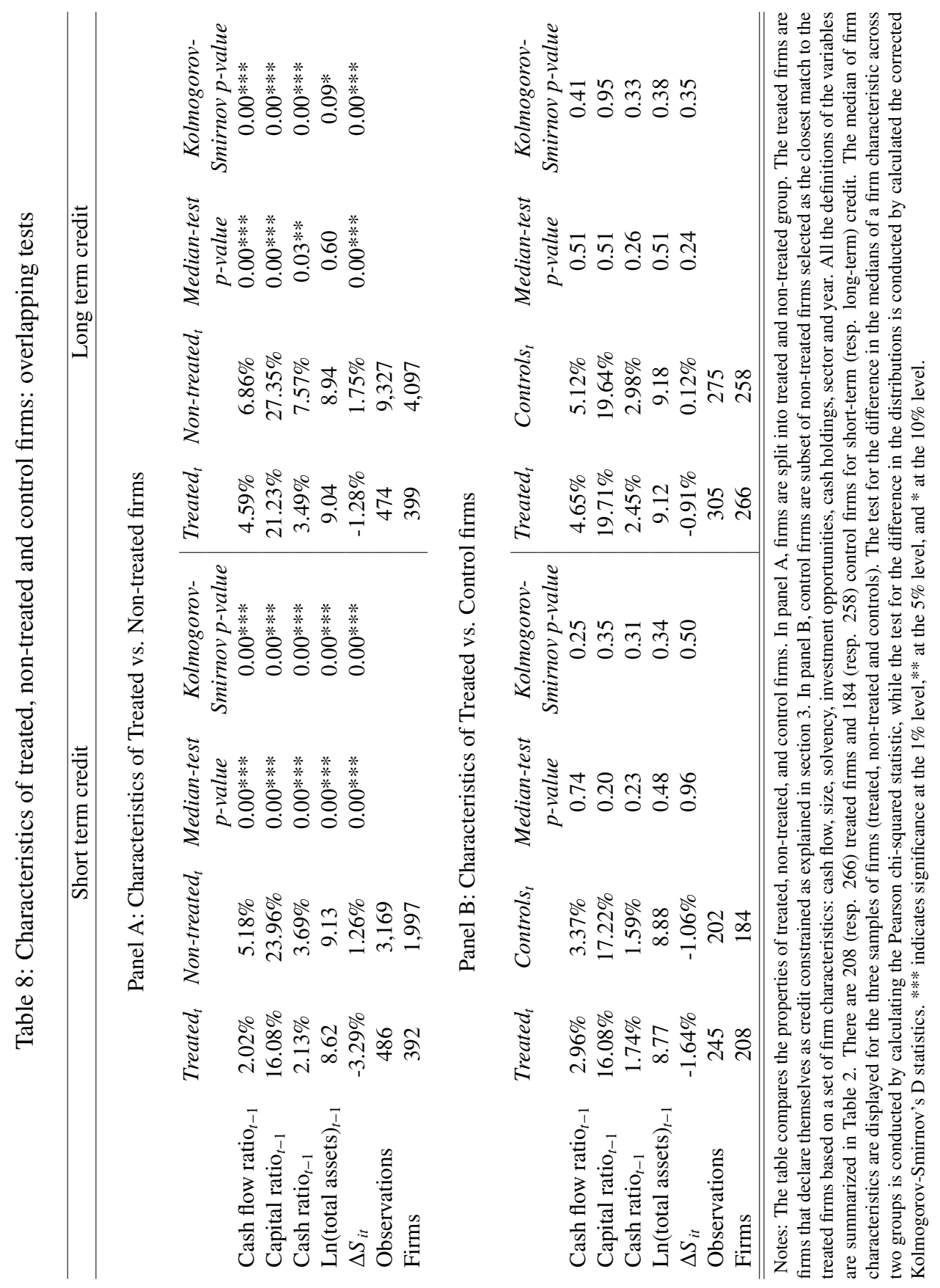


Table 9: Matching: Difference in corporate investment between treated and control firms

\begin{tabular}{lcc}
\hline & \multicolumn{2}{c}{ Difference between treated and control firms } \\
\cline { 2 - 3 } & \multicolumn{2}{c}{ Abbadie-Imbens ATT } \\
\hline & $\begin{array}{c}\text { Short-term credit } \\
\text { constraints }\end{array}$ & $\begin{array}{c}\text { Long-term credit } \\
\text { constraints }\end{array}$ \\
& $(1)$ & $(2)$ \\
\hline \multirow{2}{*}{$I_{i t} / A_{i t-1}$ (tangible) } & $-0.012^{* * *}$ & $-0.007^{* *}$ \\
& $(0.004)$ & $(0.003)$ \\
$I_{i t} / A_{i t-1}$ (all fixed assets) & $-0.009^{* *}$ & $-0.009^{* *}$ \\
& $(0.004)$ & $(0.002)$ \\
\hline Number of treated & 208 & 266 \\
Number of controls & 184 & 258 \\
\hline \hline
\end{tabular}

Notes: This table reports differences in annual increase in fixed capital between financial constrained firms and their matched controls. The corporate investment corresponds to the annual change in gross fixed assets (either tangible or both tangible and intangible), scaled by the beginning-of-year total assets. The financial constraint measures are based on the firm perception of its credit experience explained in section 3 . Column (1) and (2) refer to cash and investment credit constraints, respectively. Differences are computed as average treatment effects on the treated via matching estimators (ATT). Firms are matched using firm size, cash flow, solvency, cash holdings and investment opportunities. All the definitions of the variables are summarized in Table 2. Matching firms are also required to be in the same sector and in the same year. The Abadie \& Imbens [2006) estimates are obtained from the bias-corrected, heteroskedasticity-consistent estimator implemented in Abadie et al. 2004). $t$-statistics are in (parentheses) and $* * *$ indicates significance at the $1 \%$ level, $* *$ at the $5 \%$ level, and $*$ at the $10 \%$ level.

Table 10: Index of Cash Credit Constraints: Heckman probit results

\begin{tabular}{|c|c|c|}
\hline Dependent variable & $\begin{array}{l}\text { The firm has a positive } \\
\text { cash credit demand } \\
\text { (1) }\end{array}$ & $\begin{array}{l}\text { The firm is short-term } \\
\text { credit constrained } \\
\text { (2) }\end{array}$ \\
\hline \multirow[t]{2}{*}{ Capital ratio ${ }_{t-1}$} & $-0.371 * * *$ & $-1.345^{* * *}$ \\
\hline & $(0.076)$ & $(0.208)$ \\
\hline \multirow{2}{*}{ Cash ratio ${ }_{t-1}$} & $-2.694 * * *$ & $-2.622 * * *$ \\
\hline & $(0.128)$ & $(0.454)$ \\
\hline \multirow{2}{*}{$\operatorname{Ln}(\text { total assets })_{t-1}(\log )$} & $0.030 * * *$ & $-0.116 * * *$ \\
\hline & $(0.007)$ & $(0.023)$ \\
\hline \multirow[t]{2}{*}{ Cash flow ratio ${ }_{t-1}$} & $-0.407 * * *$ & $-3.774 * * *$ \\
\hline & $(0.185)$ & $(0.520)$ \\
\hline \multirow[t]{2}{*}{$\operatorname{Age}_{t-1}$} & $-0.042 * * *$ & $-0.122 * * *$ \\
\hline & $(0.016)$ & $(0.040)$ \\
\hline \multirow{2}{*}{ Trade credit ratio ${ }_{t-1}$} & $0.250 * * *$ & \\
\hline & $(0.087)$ & \\
\hline Sector fixed effects & Yes & Yes \\
\hline Year fixed effects & Yes & Yes \\
\hline Observations & 23,419 & 3,655 \\
\hline Number of firms & 7,028 & 2,225 \\
\hline
\end{tabular}

Notes : This table presents a probit estimation of the firm likelihood to be cash credit constrained using an Heckman two-step methodology to account for selection bias related to non-random positive credit demand. Column (1) and column (2) correspond to the first and the second stage, respectively. All regressions were estimated with a constant and include sector and year fixed-effects. See section 5 for more details. All the definitions of the variables are summarized in Table 2.*,** and *** indicate significance levels at $10 \%$, $5 \%$ and $1 \%$ respectively. 
Table 11: Index of Investment Credit Constraints: Heckman probit results

\begin{tabular}{|c|c|c|}
\hline Dependent variable & $\begin{array}{c}\text { The firm has a positive } \\
\text { investment credit demand }{ }_{t} \\
\text { (1) }\end{array}$ & $\begin{array}{l}\text { The firm is long-term } \\
\text { credit constrained } \\
\text { (2) }\end{array}$ \\
\hline \multirow[t]{2}{*}{ Capital ratio ${ }_{t-1}$} & 0.030 & $-1.108 * * *$ \\
\hline & $(0.058)$ & $(0.179)$ \\
\hline \multirow[t]{2}{*}{ Cash ratio $t-1$} & $-0.964 * * *$ & $-1.068 * * *$ \\
\hline & $(0.074)$ & $(0.259)$ \\
\hline \multirow[t]{2}{*}{$\operatorname{Ln}(\text { total assets })_{t-1}(\log )$} & $0.035 * * *$ & -0.001 \\
\hline & $(0.006)$ & $(0.015)$ \\
\hline \multirow[t]{2}{*}{ Cash flow ratio ${ }_{t-1}$} & $3.263 * * *$ & $-1.209 * * *$ \\
\hline & $(0.144)$ & $(0.443)$ \\
\hline \multirow[t]{2}{*}{$\operatorname{Age}_{t-1}$} & $0.070 * * *$ & $-0.091 * * *$ \\
\hline & $(0.014)$ & $(0.033)$ \\
\hline \multirow{2}{*}{ Investment rate ${ }_{t-1}$} & $0.195 * * *$ & \\
\hline & $(0.049)$ & \\
\hline Sector fixed effects & Yes & Yes \\
\hline Year fixed effects & Yes & Yes \\
\hline Observations & 23,419 & 9,801 \\
\hline Number of firms & 7,028 & 4,220 \\
\hline
\end{tabular}

Notes : This table presents a probit estimation of the firm likelihood to be investment credit constrained using an Heckman two-step methodology to account for selection bias related to non-random positive credit demand. Column (1) and column (2) correspond to the first and the second stage, respectively. All regressions were estimated with a constant and include sector and year fixed-effects. See section 5 for more details. All the definitions of the variables are summarized in Table 2,*,** and *** indicate significance levels at $10 \%, 5 \%$ and $1 \%$ respectively.

Table 12: Dynamic panel model: Summary statistics

\begin{tabular}{|c|c|c|c|c|c|}
\hline & Mean & Median & $\mathrm{Sd}$ & Min & Max \\
\hline$I_{i t} / A_{i t-1}$ & $3.33 \%$ & $1.71 \%$ & $4.94 \%$ & $0 \%$ & $31.78 \%$ \\
\hline$C F_{i t} / A_{i t-1}$ & $7.24 \%$ & $6.40 \%$ & $6.76 \%$ & $-10.09 \%$ & $30.21 \%$ \\
\hline$\Delta S_{i t}$ & $1.90 \%$ & $0.94 \%$ & $15.19 \%$ & $-37.94 \%$ & $63.19 \%$ \\
\hline$\Delta W / A_{i t-1}$ & $0.42 \%$ & $0.34 \%$ & $7.04 \%$ & $-22.07 \%$ & $23.09 \%$ \\
\hline Cash ratio $_{i t-1}$ & $12.86 \%$ & $7.85 \%$ & $13.87 \%$ & $0 \%$ & $60.50 \%$ \\
\hline Gross working capital ratio $_{i t-1}$ & $43.38 \%$ & $42.15 \%$ & $20.64 \%$ & $0 \%$ & $89.32 \%$ \\
\hline Observations & 22,608 & 22,608 & 22,608 & 22,608 & 22,608 \\
\hline Number of firms & 5,652 & 5,652 & 5,652 & 5,652 & 5,652 \\
\hline
\end{tabular}

Notes : This table presents the summary statistics of the variables used in the dynamic model of investment. $I$ denotes the firm's investment ; $A_{i t-1}$ its beginning-of-year total assets ; $\Delta S_{i t}$, its sales growth; $C F_{i t}$ its cash flow; $I$ the annual increase in its working capital, Cash ratio ${ }_{i t-1}$ the ratio of cash holdings over its total assets and Gross working capital ratio ${ }_{i t-1}$ the sum of accounts receivables and inventories over its total assets. All the definitions of the variables are summarized in Table 2 . 


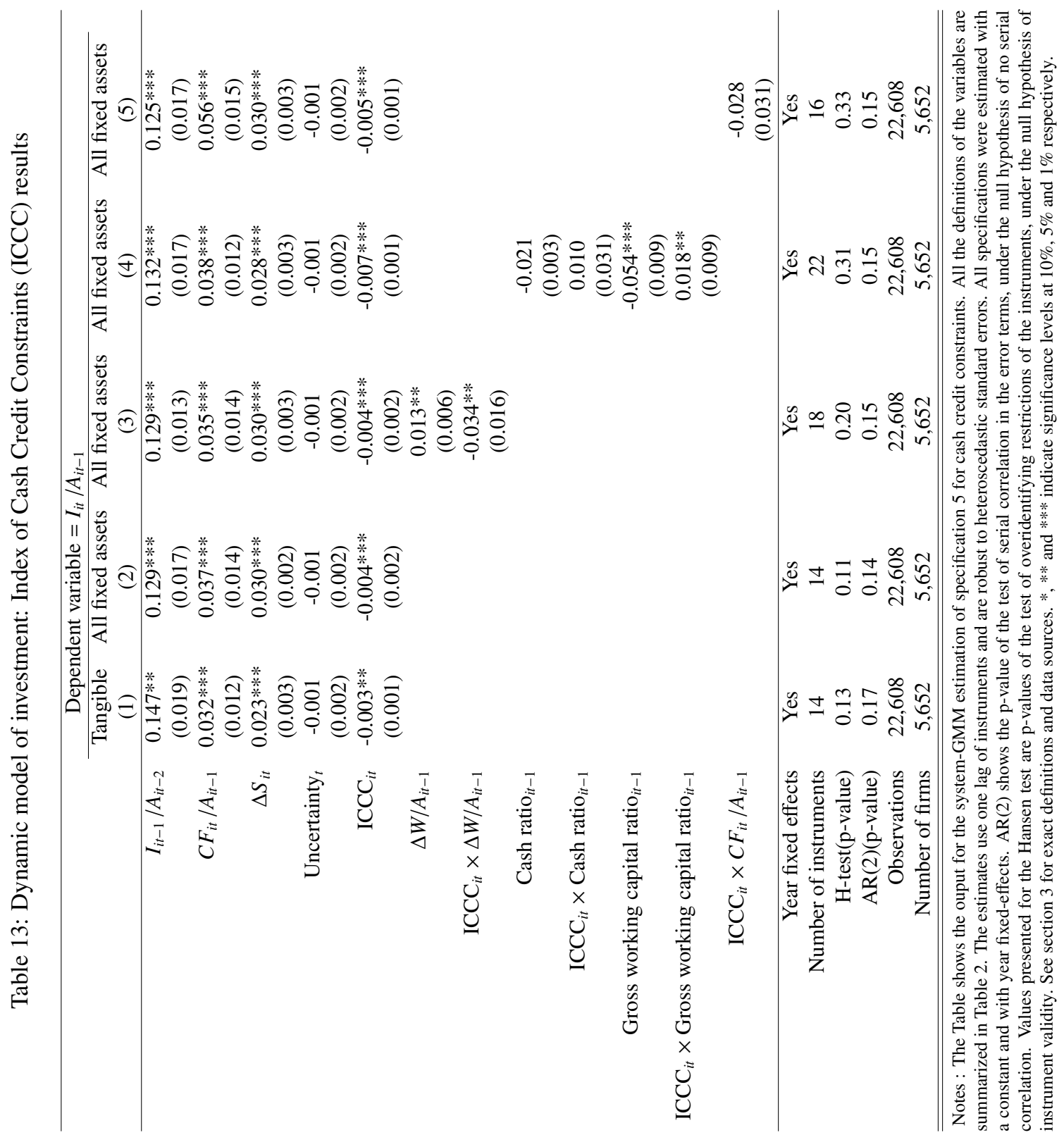




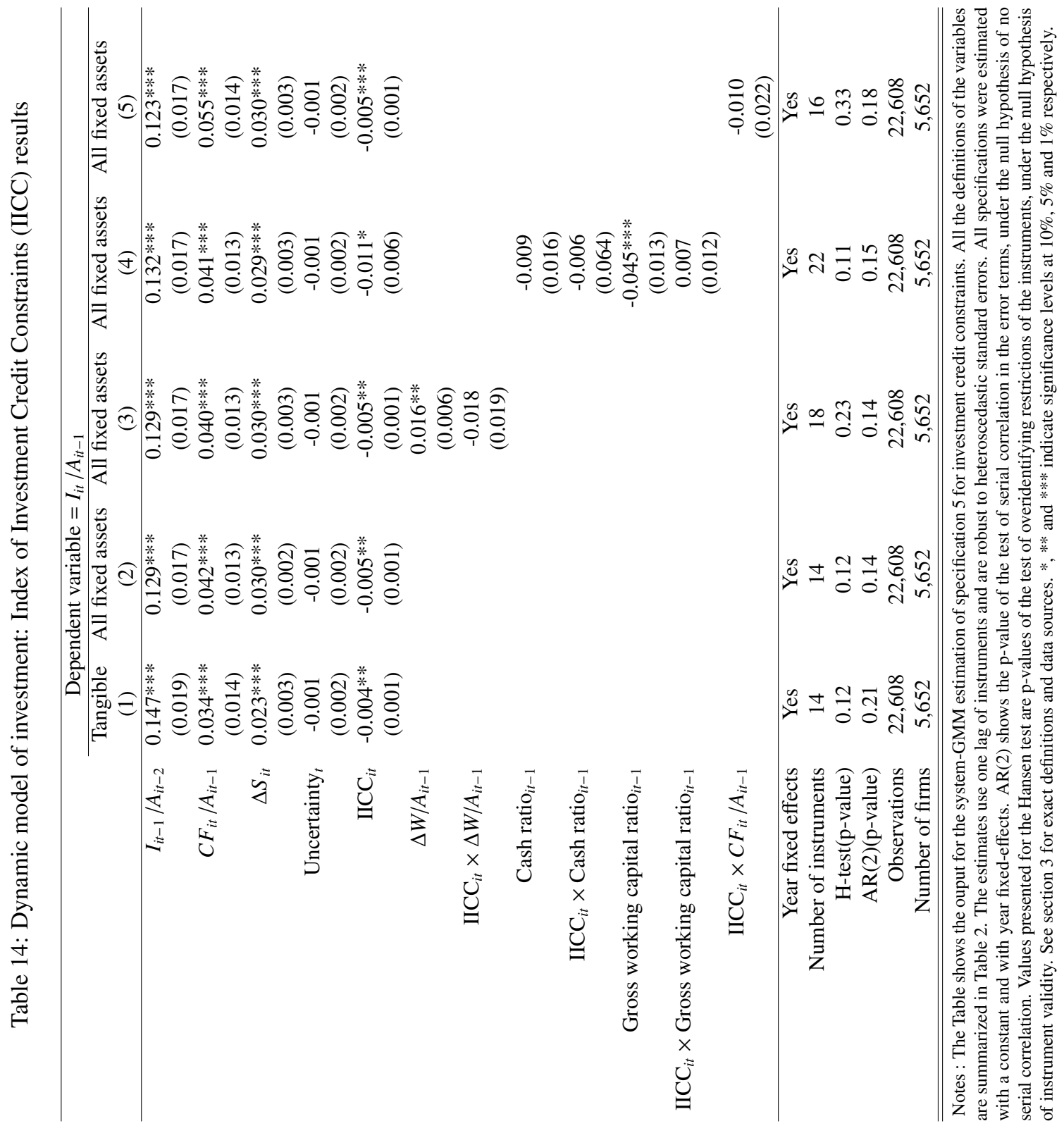




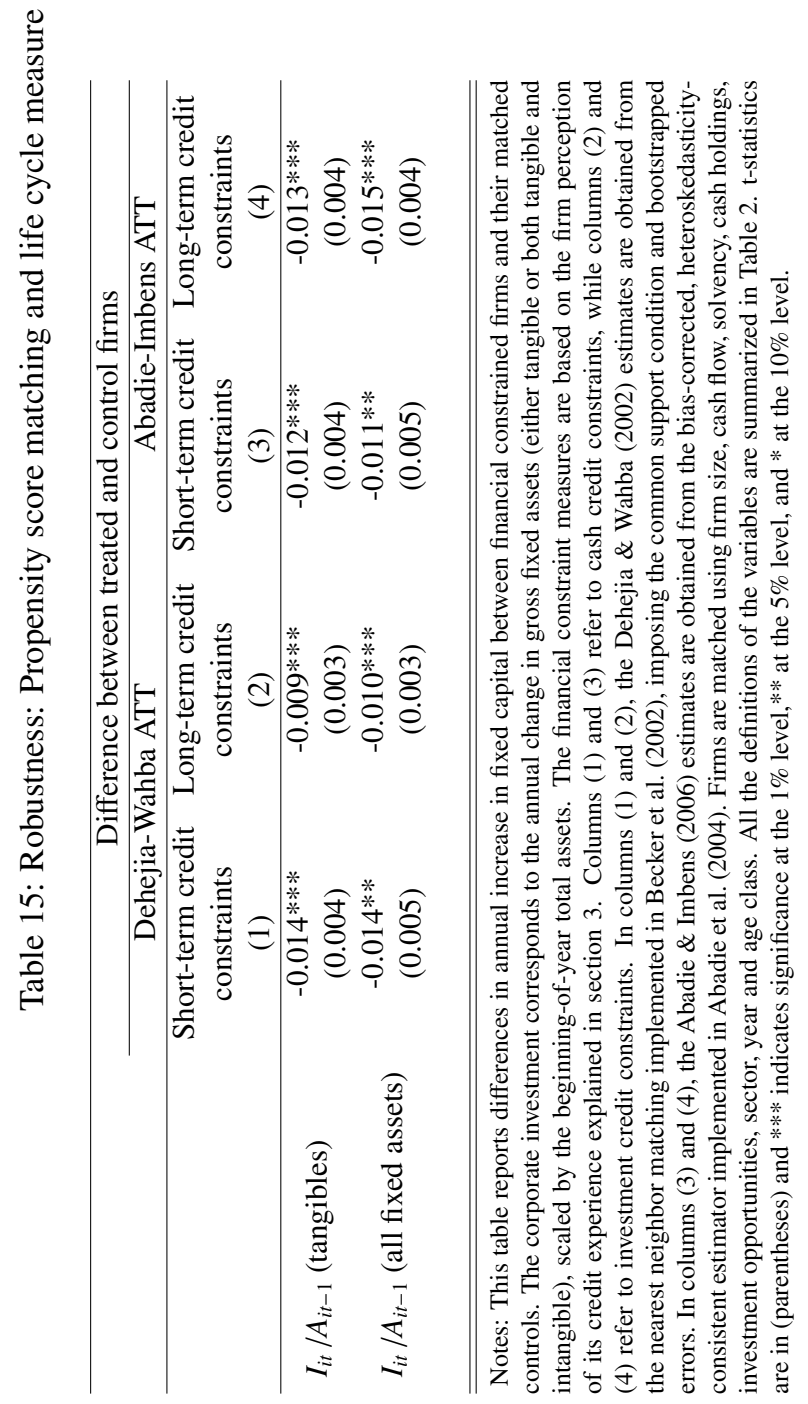


Table 16: Robustness: Quantile regressions based on matching results

\begin{tabular}{lcccccc}
\hline & \multicolumn{5}{c}{ Dependent variable $=I_{i t} / A_{i t-1}$ (all fixed assets) } \\
\cline { 2 - 7 } & \multicolumn{7}{c}{ Short-term credit } & \multicolumn{5}{c}{ Long-term credit } \\
\hline & $(1)$ & $(2)$ & $(3)$ & $(4)$ & $\mathrm{Q} 2$ & $\mathrm{Q} 3$ \\
& $0.019^{* *}$ & $0.068^{* * *}$ & $0.096^{* * *}$ & $0.064^{* * *}$ & $0.136^{* * *}$ & $0.185^{* * *}$ \\
& $(0.009)$ & $(0.016)$ & $(0.022)$ & $(0.013)$ & $(0.019)$ & $(0.035)$ \\
$\Delta S_{i t}$ & 0.002 & $0.01 A^{* *}$ & $0.051^{* * *}$ & $0.021^{* * *}$ & $0.037^{* * *}$ & $0.035^{* *}$ \\
& $(0.003)$ & $(0.008)$ & $(0.013)$ & $(0.006)$ & $(0.009$ & $(0.017)$ \\
Constrained $_{i t}$ & $-0.004^{* * *}$ & $-0.006^{* * *}$ & $-0.009^{* * *}$ & $-0.003^{* *}$ & $-0.006^{* * *}$ & $-0.009 * * *$ \\
& $(0.001)$ & $(0.002)$ & $(0.003)$ & $(0.001)$ & $(0.002)$ & $(0.003)$ \\
Uncertainty $_{t}$ & -0.001 & -0.001 & -0.001 & -0.001 & $-0.001 * * *$ & -0.001 \\
& $(0.001)$ & $(0.001)$ & $(0.001)$ & $(0.001)$ & $(0.000)$ & $(0.003)$ \\
\hline Sector fixed effects & Yes & Yes & Yes & Yes & Yes & Yes \\
Year fixed effects & Yes & Yes & Yes & Yes & Yes & Yes \\
Observations & 447 & 447 & 447 & 580 & 580 & 580 \\
Number of firms & 381 & 381 & 381 & 501 & 501 & 501 \\
Pseudo $R^{2}$ & 0.05 & 0.05 & 0.05 & 0.04 & 0.05 & 0.08 \\
\hline \hline
\end{tabular}

Notes : The Table shows the results of quantile regressions based on matching results obtained in Table 9. Constrained refers to firms that declare themselves as cash or investment credit constrained as explained in Section 3. All the definitions of the variables are summarized in Table 2. Column Q1, Q2 and Q3 present the results associated with the first Quartile, the median and the last quartile of the investment distribution. All regressions were estimated with a constant and include sector and year fixed-effects. See section 3 for exact definitions and data sources. *,** and *** indicate significance levels at $10 \%, 5 \%$ and $1 \%$ respectively. 


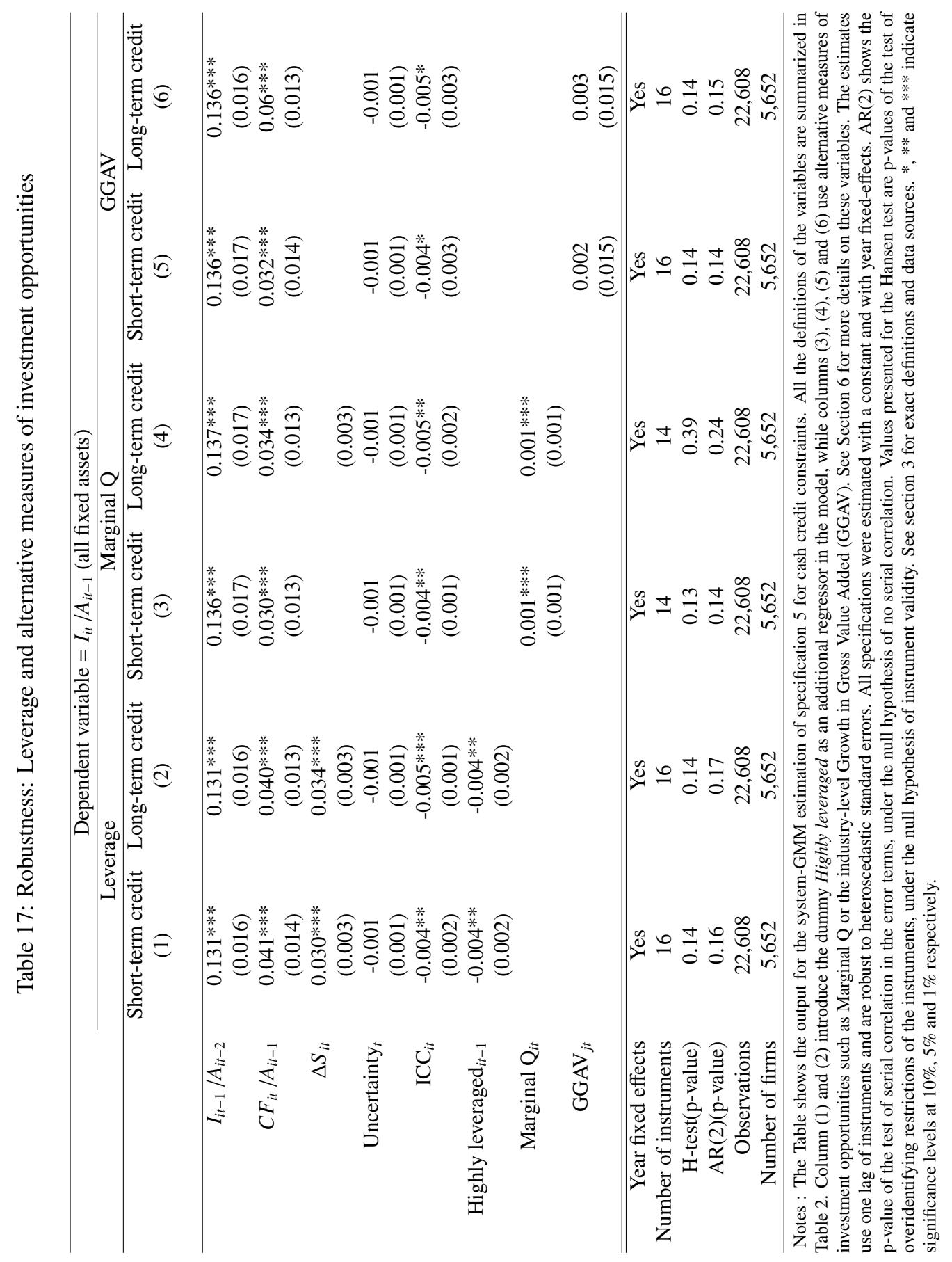

